\title{
Inducible Nitric Oxide Synthase in the Carcinogenesis of Gastrointestinal Cancers
}

\author{
Graciele Almeida de Oliveira, ${ }^{1}$ Robert Y.S. Cheng,, Lisa A. Ridnour,, Debashree Basudhar, \\ Veena Somasundaram, ${ }^{1}$ Daniel W. McVicar, Hugo Pequeno Monteiro, and David A. Wink ${ }^{1}$
}

\begin{abstract}
Significance: Gastrointestinal (GI) cancer taken together constitutes one of the most common cancers worldwide with a broad range of etiological mechanisms. In this review, we have examined the impact of nitric oxide (NO) on the etiology of colon, colorectal, gastric, esophageal, and liver cancers.

Recent Advances: Despite differences in etiology, initiation, and progression, chronic inflammation has been shown to be a common element within these cancers showing interactions of numerous pathways. NO generated at the inflammatory site contributes to the initiation and progression of disease. The amount of NO generated, time, and site vary and are an important determinant of the biological effects initiated. Among the nitric oxide synthase enzymes, the inducible isoform has the most diverse range, participating in numerous carcinogenic processes. There is emerging evidence showing that inducible nitric oxide synthase (NOS2) plays a central role in the process of tumor initiation and/or development.

Critical Issues: Redox inflammation through NOS2 and cyclooxygenase-2 participates in driving the mechanisms of initiation and progression in GI cancers.

Future Directions: Understanding the underlying mechanism involved in NOS2 activation can provide new insights into important prevention and treatment strategies. Antioxid. Redox Signal. 26, 1059-1077.
\end{abstract}

Keywords: nitric oxide, gastrointestinal cancer, liver

\section{Introduction}

$\mathbf{G}$ ASTROINTESTINAL (GI) CANCER IS a heterogeneous disease that affects the digestive system and, as a whole, is one of the most common types of cancer worldwide. Estimates for GI cancer incidence in 2016 for the largest countries in North America and South America, namely United States of America and Brazil, respectively, highlight the steadily growing number of cases. The American Cancer Society estimated 217,000 new cases and 102,700 deaths in 2016 related to colorectal, esophageal, gastric, and liver cancers together (153). The Brazilian Instituto Nacional do Cancer estimated for the year 2016, 65,610 new cases of GI cancer in Brazil (70). The etiology and acknowledged risk factors leading to GI cancer are dependent on cancer type and include hereditary conditions, microorganism and viral infections, alcoholic cirrhosis, metabolic syndrome, smoking, diet, and chronic inflammation.
The relationship between GI cancer and nitric oxide (NO) and reactive nitrogen species (RNS) was first proposed in the 1970's $(104,128,147)$. These studies postulated that nitrite $\left(\mathrm{NO}_{2}^{-}\right)$and nitrate $\left(\mathrm{NO}_{3}^{-}\right)$present in food and water were metabolized to produce carcinogenic nitrosamines (189). Nitrosamines metabolized by liver cytochrome P450 enzymes are powerful carcinogens in rodent models and function through alkylation of DNA. The presence of $\mathrm{NO}_{2}^{-}$in the stomach promotes nitrosation of different compounds, including amines. Formation of nitrosamines via acidification of $\mathrm{NO}_{2}^{-}$in the gastric compartment was prevented by the use of antioxidants, such as ascorbate and $\alpha$-tocopherol (181). Nevertheless, recent toxicological studies in rodents show no increase in incidence of cancer upon ingestion of $\mathrm{NO}_{2}^{-}$and $\mathrm{NO}_{3}^{-}$in drinking water (16). The same was observed in epidemiological studies in human as well. Reduction of $\mathrm{NO}_{2}^{-}$and $\mathrm{NO}_{3}^{-}$to $\mathrm{NO}$ by reductases has been considered an alternative source of NO generation in cells. Interestingly, studies have

\footnotetext{
${ }^{1}$ Cancer and Inflammation Program, Center for Cancer Research, National Cancer Institute, National Institutes of Health, Frederick, Maryland.

${ }^{2}$ Laboratório de Sinalização Celular, Universidade Federal de São Paulo, São Paulo, Brazil.
} 
shown that $\mathrm{NO}_{2}^{-} / \mathrm{NO}_{3}^{-}$in the diet has a positive effect on cardiovascular disease, where $\mathrm{NO}_{2}$ is converted to $\mathrm{NO}$ under hypoxia, thus abating cardiovascular conditions such as hypertension (81). These findings suggest a complex relationship between potential carcinogens and cardiovascular health.

NO is a gaseous-free radical permeable to biological membranes, which works as an intercellular and intracellular messenger playing key roles in a range of processes, including cell metabolism (28), cell death (188), and cell survival (120). The pleiotropic effects of NO in biological systems are also due to its reactivity with different cellular molecules, such as molecular oxygen $\left(\mathrm{O}_{2}\right)$, superoxide radical anion $\left(\mathrm{O}_{2}^{-}\right)$, DNA, lipids, proteins, and transition metals. NO action in cell systems depends on its steady state concentration and duration of exposure. It is also governed by cell redox state and environmental factors (174). NO plays an important role in cell signaling, stimulating cell proliferation, survival, and cell death in normal as well as in transformed cells $(30,116)$.

Nitric oxide synthases (NOS) are the main source of NO in mammalian systems. There are three well-characterized NOS isoforms encoded by three different genes: the constitutive and $\mathrm{Ca}^{+2}$-dependent isoforms include neuronal (nNOS) encoded by the gene NOS1 and endothelial (eNOS) encoded by the gene NOS3. The $\mathrm{Ca}^{+2}$-independent and inducible nitric oxide synthase (NOS2) is encoded by the gene NOS 2 . These isoforms share at least $50 \%$ sequence homology, but differ in structure, function, and catalytic activity. They are expressed in a variety of cell types, and isoform-specific domains direct cellular compartmentalization (163).

While NOS1 and NOS3 are constitutively expressed (constitutive NOS, cNOS) (114), NOS2 activity is induced by inflammatory cytokines, endotoxin stimulation, and hypoxic conditions (46). NOS isoforms generate NO at different levels. Under physiological conditions, cNOS generates NO in the picomolar $(\mathrm{p} M)$ to nanomolar $(\mathrm{n} M)$ concentration range upon transient increases in intracellular $\mathrm{Ca}^{2+}$ levels. The inducible isoform can produce NO at micromolar $(\mu M)$ concentrations and its activity is sustained (173).

Tumor is not composed exclusively of abnormal cells, but it also contains stromal cells, including cancer-associated fibroblasts, immune cells such as $\mathrm{T}$ lymphocytes, tumorassociated macrophages, and polymorphonuclear leukocytes, as well as perivascular cells, endothelial cells, and mesenchymal stem cells. These stromal cells secrete a range of molecules into the extracellular tumor microenvironment, such as growth factors, cytokines, and NO. Tumor tissue can express different levels of NOS according to the disease stage. The tumor growth environment also contributes to establishment of NO steady state levels and activates important cell signaling pathways (48). NO plays an important role in cell signaling and can control cell death and survival in normal tissue and in pathological states.

\section{Inflammatory response in development and progress of GI cancer}

In support of a role of inflammation in the initiation of cancer, early studies have shown that aspirin and other nonsteroidal anti-inflammatory drugs (NSAIDs), which inhibit cyclooxygenase $(\mathrm{COX})$ enzyme, can delay or prevent the occurrence of colorectal polyps, colorectal cancer, and other GI tumors (59). Inflammation is associated with various cancers (90), including colorectal, gastric, and esophageal cancer $(6,106,130,177)$, and it is a component present in all stages of tumor development, including initiation, promotion, and disease progression (106). Cyclooxygenases 1 and 2 (COX1, COX2) are enzymes that catalyze the formation of paracrine hormones (prostaglandins) from arachidonic acid and play an important role in inflammation. While $C O X 1$ is constitutively expressed in most cells, $C O X 2$ remains undetectable but is induced upon stimulation by bacterial endotoxins, lipopolysaccharides (LPS), cytokines, grown factors, and hormones that promote inflammation, hence making it a marker of inflammatory response (11).

Carcinogenesis is a complex process, but essentially occurs due to a series of mutations leading to altered gene expression and loss of proliferative control (185). Chronic inflammation promotes NO generation through NOS2 and this event is associated with induction of neoplastic transformation. NO and other RNS can induce DNA damage by inhibition of DNA repair activities (187) or by direct modification of the DNA structure, such as nitrosative deamination, nitrosamine formation, DNA alkylation, or DNA strand breaks (168).

More than $50 \%$ of all human tumors have mutations in the tumor suppressor protein p53 and/or proteins that regulate its function (2). p53 status is a common biomarker in clinical studies of cancers, including breast $(29)$, colorectal $(72,150)$, gastric (61), and esophageal cancer (63), as well as other cancers (131). As a tumor suppressor, p53 has multiple roles in cell signaling. The activation of p53 induces the expression of a range of genes that can cause cell cycle arrest of damaged cells to facilitate repair or the induction of apoptosis (19). Exposure of cells to an exogenous NO donor or increased expression of NOS2 leads to accumulation of p53 protein (45, $62,172)$. Interestingly, p53 also modulates inflammatory response as it negatively regulates NOS2 expression. Accordingly, loss of p53 function has been shown to augment the expression of NOS2 and contribute to increased COX2 expression and increased tumor growth (180). Moreover, Hofseth et al. found that exogenous NO increased the expression and posttranslational modifications of $\mathrm{p} 53$ in vitro, in a model compatible with chronic inflammation. In the same study, they observed that samples from patients with colon cancer-prone chronic inflammatory disease had increased p53 phosphorylation, which correlated with enhanced NOS2 expression (62).

Studies performed in the 1990's with NO donors and NOS inhibitors showed a relationship between NO and induction of inflammatory factors. Early observations described the positive effects of $\mathrm{NO}$ and RNS on COX2 expression and activity (52). Subsequent studies found that NO-dependent stimulation of COX2 expression in tumor cells was abated by NOS2 inhibitors $(71,146)$. In human colorectal tumors, NOS2 expression correlates with $\mathrm{COX} 2$ expression and NOS2 inhibition reduced COX2 activity (27). Interestingly, NOS2 inhibitors decreased aberrant crypt foci (ACF) in rat colonic mucosa and this effect was coupled with decreased COX2 expression in a model of azoxymethane-induced ACF formation, which is one of earliest changes associated with colon cancer risk (137).

Numerous studies showed that NOS2 and COX2 expression levels are coordinately induced in tumor cells indicating interplay between these enzymes in cancer. Furthermore, 
NOS2 can augment COX2 expression and vice versa (56, 159). Moreover, both NOS 2 and COX 2 are regulated by the $\mathrm{NF} \kappa \mathrm{B}$ pathway $(87,154)$ and induced by interferon gamma $(\operatorname{IFN} \gamma)(113,166) . \mathrm{NF} \kappa \mathrm{B}$ is considered to be the primary inflammation-associated transcription factor due to its activation by multiple cytokines and pathogens (126). The relationship between these enzymes in chronic inflammation and their actions as regulators of production of $\mathrm{NO}$ in this process is summarized in Figure 1.

\section{NOS2 expression in Gl cancer}

Many studies have shown a relationship between NOS2 expression and cancer risk and development. To better examine and understand the NOS 2 gene expression status in cancer versus their normal counterpart, the FireBrowse gene expression viewer was used to visualize expression data collected from various whole genome RNA-Seq studies. The RSEM (RNA-

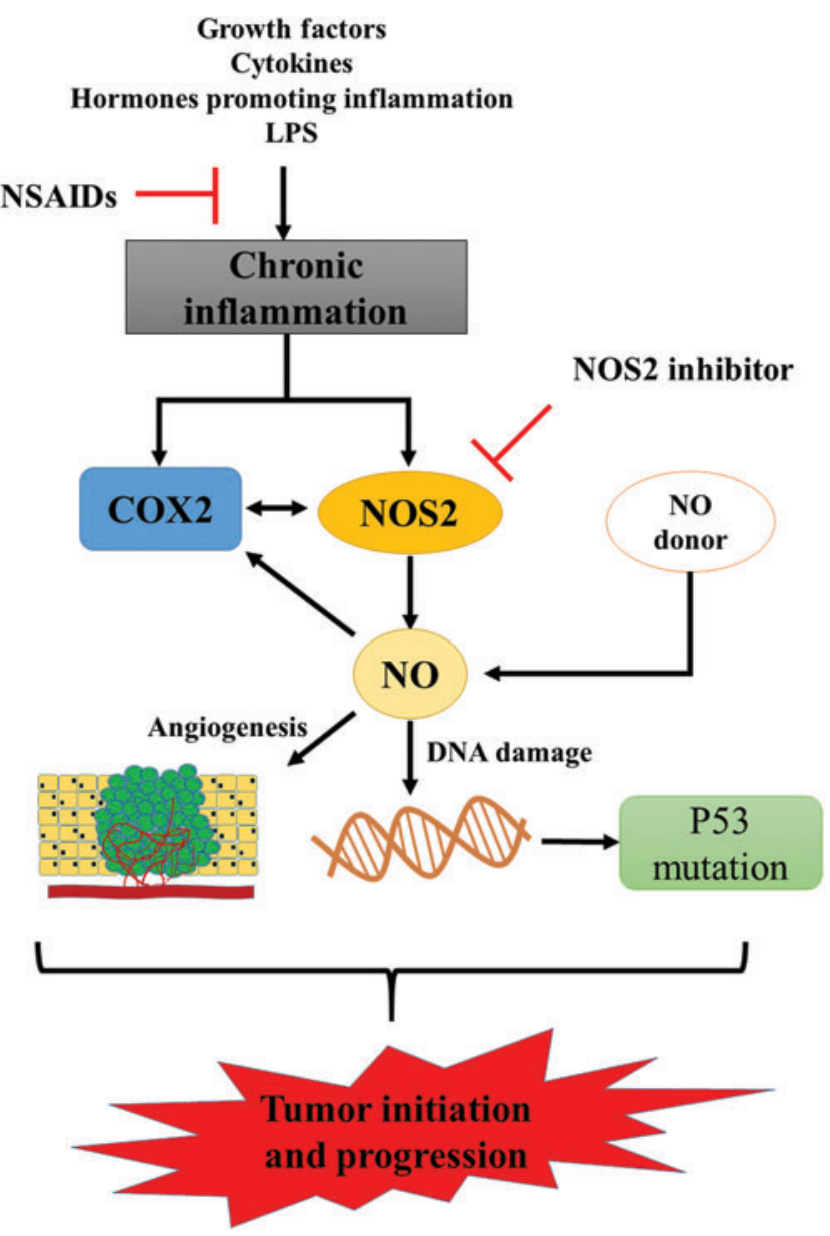

FIG. 1. Inflammation, NO, and tumor development. Schematic illustration of pathways associated with chronic inflammation and tumor development. The use of NSAIDs or NOS2 inhibitors is associated with abrogation of processes involved in tumor initiation and development, thus highlighting the participation of NOS2 in this process. NO, nitric oxide; NOS2, inducible nitric oxide synthase; NSAIDs, nonsteroidal anti-inflammatory drug. To see this illustration in color, the reader is referred to the web version of this article at www.liebertpub.com/ars
Seq by Expectation Maximization) mRNASeq expression profiles for each The Cancer Genome Atlas (TCGA) disease chart are shown in Figure 2. Using this approach, we found that NOS2 gene expression was detected in all cancer types and most corresponding normal tissues, which represent nearly all organs/ systems. Interestingly, majority of cancer data appeared to have larger error bars in their expression levels compared to their normal counterparts, which are likely a reflection of the heterogeneous nature of the cancer itself. The transcriptome data would be more accurate and represent the real expression level of NOS2 gene in cancer if those RNA-Seq studies were performed on laser-captured microdissected cancer samples (50). In GI tumors, our analysis shows that NOS 2 gene expression is downregulated in colon adenocarcinoma (COAD) and colorectal adenocarcinoma, but in rectum adenocarcinoma, NOS2 expression shows an upward trend when compared to the corresponding controls. Expression is also upregulated in esophagus adenocarcinoma, stomach adenocarcinoma, and stomach and esophageal carcinoma. In the case of hepatocellular carcinoma (HCC), there is an elevated expression level of NOS2 relative to normal tissue. The high expression of NOS 2 in liver cancer is not surprising since high NOS2 levels have been found under a variety of conditions in hepatocytes.

\section{Regulation of NOS2 and genetic alterations in GI}

The expression of NOS 2 mRNA is induced and regulated by different agents that activate different cell signaling pathways associated with a number of transcription factors. Nevertheless, induction of NOS2 is cell and species specific (86). In fact, mammal's NOS 2 promoter possesses transcription factor binding sites for $\mathrm{NF} \kappa \mathrm{B}, \mathrm{NF}-\mathrm{IL} 6$, and octamer factor-a transcription factor induced by tumor necrosis factor alpha (TNF $\alpha)$ and IFN $\gamma$ (86). NOS2 expression may also be modulated by other mechanisms, including protein translation and NOS2 mRNA stability $(20,97)$, changes in substrate availability (supply and uptake) (117), presence or absence of cofactors (171), posttranslational modifications (119), formation of dimers (1), degradation (42), and localization in various tissues (141) and cell types.

The NOS2 promoter sequence contains binding sites for a range of transcription factors regulated by different pathways. The human NOS 2 promoter has a site for binding $\mathrm{NF} \kappa \mathrm{B}$ and the signal transducer and activator of transcription-1 $\alpha$ (STA$\mathrm{T} 1 \alpha$ ), which regulates NOS2 expression (49). Interestingly, changes in cell signaling pathways associated with these transcriptional factors are also associated with malignant development $(57,107)$.

The query interface of cBioPortal enabled us to explore the impact of altered NOS 2 genomic sequence in a multidimensional cancer genomics database. The analysis result reveals that low frequency genomic alteration rate of the NOS 2 gene still can be associated with GI cancers. Relatively, genomic mutations appeared to be the dominant type of alteration among the studies analyzed here (Fig. 3).

\section{NOS2 and microRNA}

To better understand the NOS2 gene relationship/interaction with other gene(s) in GI tumors, we adopted the Regulome Explorer (Fig. 4) to examine what gene(s) is/are associated with the NOS2 regulome based upon their genomic context. The circular layout displays the associations as 


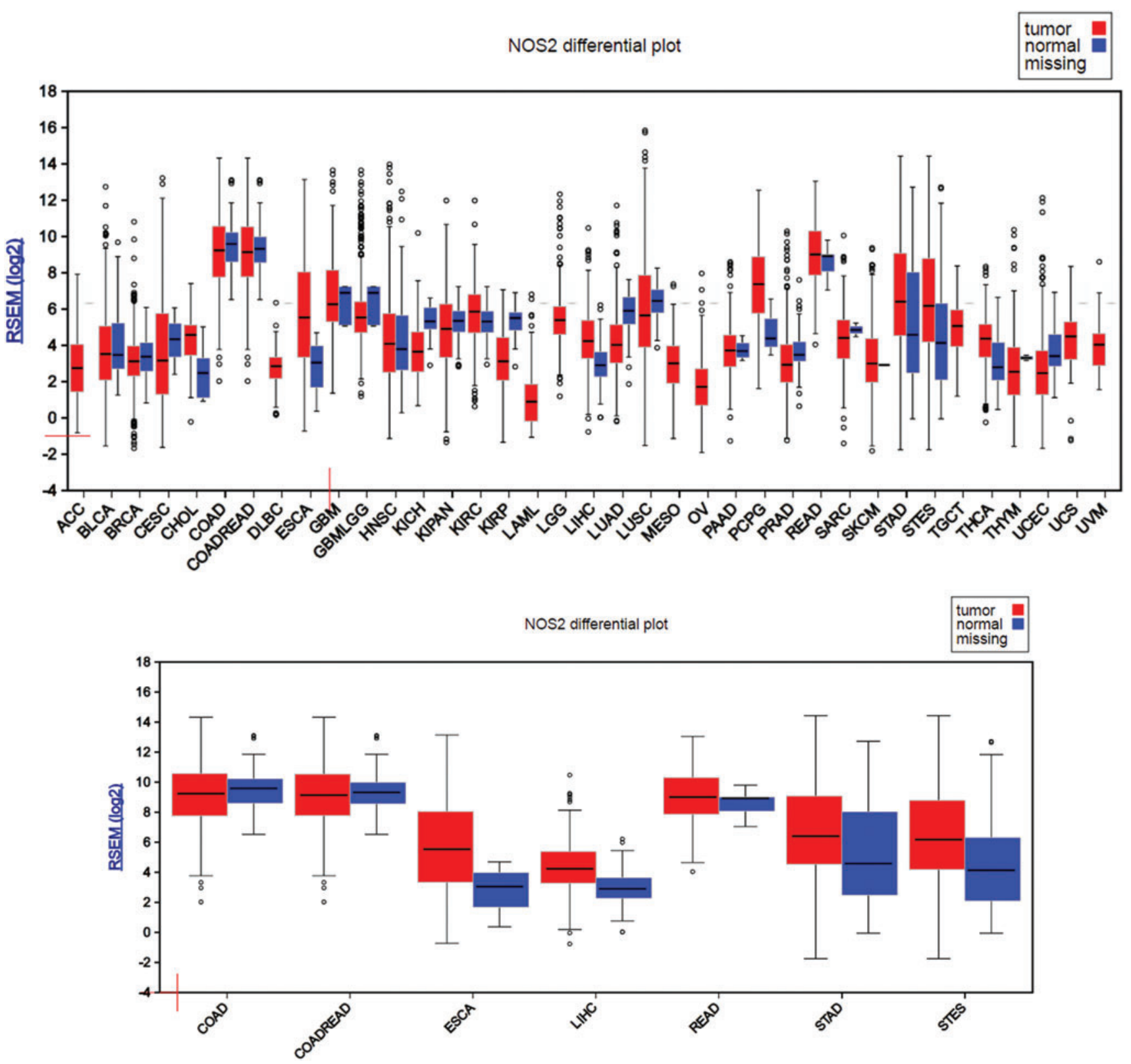

FIG. 2. NOS2 gene expression status in cancer versus their normal counterpart. FireBrowse Gene Expression Viewer (Board Institute of MIT and Harvard; http://firebrowse.org). NOS2 gene expression status is shown in different types of cancer (upper panel) and in gastrointestinal cancer (lower panel). ACC, adrenocortical carcinoma; BLCA, bladder invasive carcinoma; BRCA, breast invasive carcinoma; CESC, cervical and endocervical cancer; CHOL, cholangiocarcinoma; COAD, colon adenocarcinoma; COADREAD, colorectal adenocarcinoma; DLBC, lymphoid neoplasm diffuse large $\beta$-cell lymphoma; ESCA, esophageal carcinoma; GBM, glioblastoma multiforme; GNMLGG, glioma; HNSC, head and neck squamous cell carcinoma; KICH, kidney chromophobe, KIPAN, pan kidney cohort (KICH, KIRK, and KIRP); KIRC, kidney renal clear-cell carcinoma; KIRP, kidney renal papillary-cell carcinoma; LAMIL, acute myeloid leukemia; LGG, brain lower grade glioma; LIH, liver hepatocellular carcinoma; LUAD, lung adenocarcinoma; LUSC, lung squamous cell carcinoma; MESO, mesothelioma; OV, ovarian serous cystadenocarcinoma; PAAD, pancreatic adenocarcinoma; PCPG, pheochromocytoma and paraganglioma; PRAD, prostate adenocarcinoma; READ, rectum adenocarcinoma; SARC, sarcoma; SKCM, skin cutaneous melanoma; STAD, stomach adenocarcinoma; STES, stomach and esophageal carcinoma; TGCT, testicular germ cell tumors; THCA, thyroid carcinoma; THYM, thymoma; UCEC, uterine corpus endometrial carcinoma; UVM, uveal carcinoma. To see this illustration in color, the reader is referred to the web version of this article at www.liebertpub.com/ars

edges in the center connecting the features (with genomic coordinates) displayed around the perimeter. The ring displays cytogenetic bands. Using this multiscale association explorer, gene-gene associations are primarily displayed within the context of genomic coordinates. Surprisingly, the analysis result based upon the GI cancer data in the TCGA database revealed most associated genes are microRNA (miRNA). miRNAs are short noncoding RNAs that actively participate in the regulation of virtually all biological pathways. Accordingly, miRNAs influence numerous cancer-relevant 


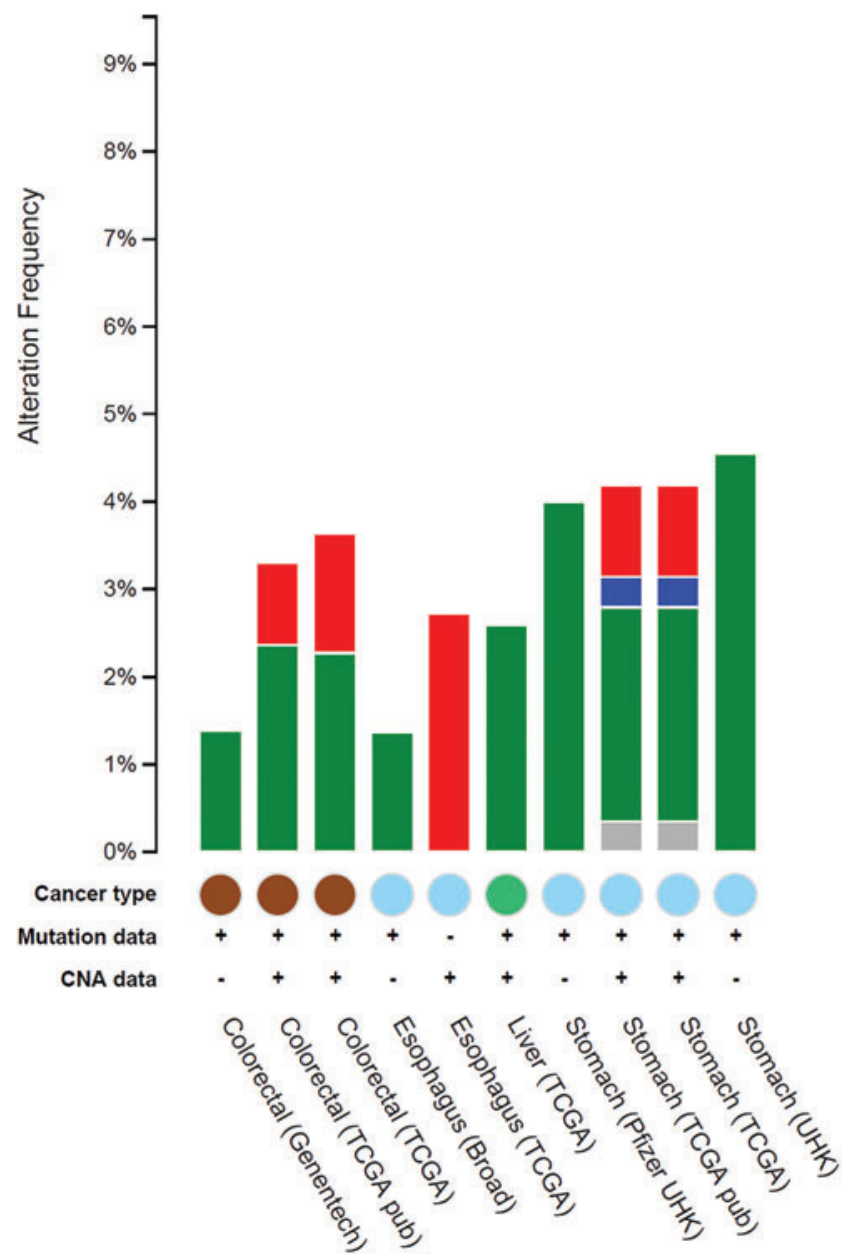

FIG. 3. cBioPortal cross-cancer alteration analysis. The graph represents the frequency of alterations in NOS2 gene, where green is the frequency of mutation, blue is deletions, red is amplification, and gray is associated with multiple alterations. The graph was generated through cBioportal at Memorial Sloan Kettering Cancer Center, http://cbioportal. org. To see this illustration in color, the reader is referred to the web version of this article at www.liebertpub.com/ars

processes such as proliferation, cell cycle control, apoptosis, differentiation, migration, and metabolism. We were able to identify eight miRNAs associated with NOS2 gene expression in COAD, 12 miRNAs associated with NOS2 gene expression in stomach carcinoma, and a total of 44 genes/ miRNAs associated with NOS2 gene expression in colorectal carcinoma (Fig. 4).

\section{Colorectal Cancer}

Colorectal cancer is the third most common cancer worldwide. In 2016, it is estimated that more than 130,000 new cases of colorectal cancer will be diagnosed in the United States alone (153). In Brazil, 34,280 new cases are estimated for 2016 (70). Among human cancers, colorectal cancer is the one most closely associated with chronic inflammation. NOS2-derived NO, generated at inflammatory sites, stimulates colon tumor progression (139). Imbalance in NOS2 expression is associated with events leading to tumor initiation and development. Studies in the early 2000's showed the presence of NOS2 in 50-60\% of colon cancer patients and that NOS 2 expression correlated with decreased long-term survival and increased incidence of lymph node metastasis and lymphatic invasion $(94,122)$. These studies suggested that colorectal cancer cells expressing high levels of NOS2 predicted poor outcome. NOS2 expression levels vary within the colorectal tissue, while rectal and lower colon displays low NOS2 expression and upper colon shows increased expression of the enzyme. Although NOS2 expression has been associated with colorectal cancer progression, its role during tumor development is not completely understood. While some studies show a direct correlation between NOS2 expression levels, tumor development, and poor patient outcome, others describe reduced NOS2 expression levels early in colorectal tumor progression. A more recent study shows an interesting dichotomy between NOS2 expression site and patient survival. Unlike that found in tumor cells, increased NOS2 expression in tumor infiltrating macrophages is associated with positive patient outcome. Therefore, the source of NOS2, for example, immune cells versus tumor, is important in prediction of the outcome of colon cancer (121).

Further evidence of elevated levels of NO in colorectal cancer comes from footprints such as nitrotyrosine formation and $S$-nitrosation of protein thiols. A study showed that abnormal $S$-nitrosation induced by the activation of NOS2 modulates inflammation and cancer (25). On the contrary, Hao et al. showed that NOS2 protein levels were markedly reduced in ACF or at multiple neoplastic lesions, when compared to normal adjacent tissue (57a). These observations suggest that loss of NOS2 expression in colonic epithelium may be an early event in colorectal cancer development. However, NOS2 expression levels are elevated in the colonic mucosa of inflammatory bowel disease (IBD) and Crohn's disease (CD) (33). However, later in progression, it has been found that there is constitutive expression of NOS2 in colorectal cancer stem cells and this has been correlated with the tumor initiating properties of these cells (132). Interestingly, not all NOS isoforms have the same pattern of expression in inflammation-associated disease. Taken together, NOS2 likely has diverse roles in induction and early progression of colorectal cancer but appears to be a poor prognostic indicator in more advanced stages of the disease. Below, we examine some of the different ways in which NO can affect the progression and prognosis of this disease.

The transformation of a normal epithelial cell to colorectal carcinoma is a complex and multistep process, associated with multiple genetic changes (18). In general, normal epithelial cells first form noncancerous polyps, then progress to adenomas, and finally develop into carcinomas (75). Changes in the gut microbiota and their metabolic products have been linked to inflammatory processes associated with ulcerative colitis (UC), CD (100), and development and progression of colorectal cancer (195). Inflammatory processes found in colitis, such as macrophage activation, are considered a high risk factor for malignancy (39), and NO generation at sites of inflammation has been implicated as one of the causes for colorectal cancer development.

Beyond the etiology of cancer, NOS2 has emerged as an important component of progression to more aggressive 


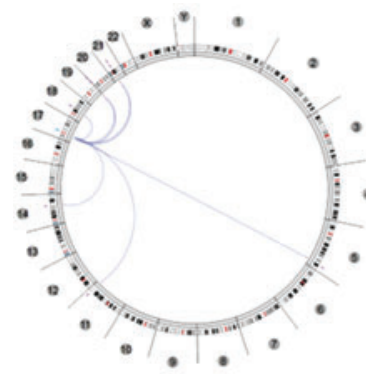

Colon adenocarcinoma

\begin{tabular}{l} 
hsa-mir-99b \\
hsa-mir-99a \\
hsa-mir-625 \\
hsa-mir-187 \\
hsa-mir-146a \\
hsa-mir-125b-1 \\
hsa-mir-125a \\
hsa-let-7c \\
\hline
\end{tabular}
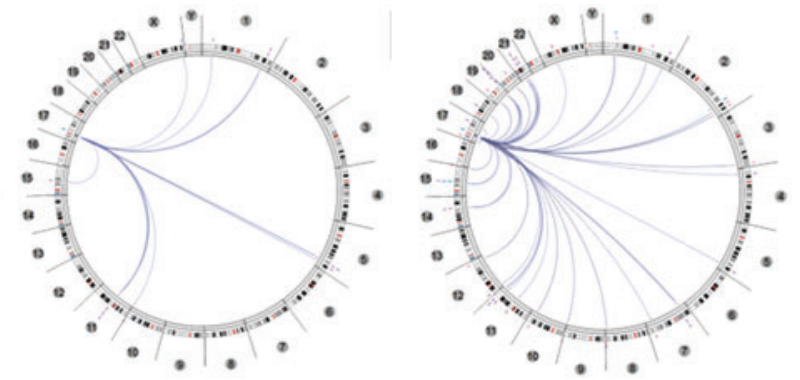

Stomach adenocarcinoma Colorectal carcinoma

$\begin{array}{lll}\text { hsa-miR-215 } & \text { ZC3H12A } & \text { hsa-miR-34c-5p } \\ \text { hsa-miR-378a-3p } & \text { DUOXA2 } & \text { hsa-let-7e-5p } \\ \text { hsa-miR-194-3p } & \text { DUOX2 } & \text { hsa-miR-155-3p } \\ \text { hsa-miR-192-5p } & \text { CASP10 } & \text { NOTCH1 } \\ \text { hsa-miR-146a-5p } & \text { hsa-miR-146a-5p } & \text { hsa-miR-218-5p } \\ \text { hsa-miR-194-5p } & \text { hsa-miR-625-3p } & \text { PXN } \\ \text { hsa-miR-147b } & \text { hsa-miR-215 } & \text { DVL3 } \\ \text { hsa-miR-378a-5p } & \text { hsa-let-7c } & \text { hsa-miR-187-3p } \\ \text { hsa-miR-192-3p } & \text { hsa-miR-125b-5p } & \text { hsa-miR-150-5p } \\ \text { hsa-miR-378c } & \text { hsa-miR-99a-5p } & \text { hsa-miR-148a-3p } \\ \text { hsa-miR-552 } & \text { hsa-miR-125b-2-3p } & \text { hsa-miR-222-5p } \\ \text { hsa-miR-509-3p } & \text { hsa-miR-194-3p } & \text { hsa-miR-490-3p } \\ & \text { CASP7 } & \text { SRC (pY527) } \\ & \text { hsa-miR-147b } & \text { CLDN7 } \\ & \text { hsa-miR-625-5p } & \text { FN1 } \\ & \text { hsa-miR-21-3p } & \text { NOTCH3 } \\ & \text { hsa-miR-99b-5p } & \text { IGF1R } \\ & & \\ & \text { hsa-miR-155-5p } & \text { PTK2 } \\ & \text { hsa-miR-100-5p } & \text { PEA15 } \\ & \text { hsa-miR-200c-5p } & \text { YBX1 (pS102) } \\ & \text { hsa-miR-148a-5p } & \text { IRS1 } \\ & \text { hsa-miR-125a-5p } & \\ & & \\ & & \\ & & \end{array}$

FIG. 4. Genes associated with the NOS2 regulome. To see this illustration in color, the reader is referred to the web version of this article at www.liebertpub.com/ars tumors. In the late 1980's and early 1990's, NOS2 was shown to be a component of the tumoricidal activity of the immune system. However, in the mid 1990's, studies showed that NOS2 may promote tumorigenesis. Jenkins et al. showed that NOS2 overexpression in a human COAD cell line increases tumor growth and vascularization in nude mice (77). Later, it was shown that NOS 2 mRNA, protein, and activity were increased in human colon adenoma and carcinoma $(3,89)$. These findings suggest that NOS2 expression within the cancer cell promotes progression, while NOS2 expression in the tumor-associated microenvironment could potentially have diametrically opposite effects.

The adenomatous polyposis coli $(A P C)$ is a tumor suppressor gene. Mutations in the APC gene are commonly found in colorectal cancers (124) and are also found in other cancers such as breast cancer (111), gastric adenocarcinoma (193), and esophageal cancer (13). APC is a protein member of Wnt signal transduction pathway. The APC complex consists of axin, casein kinase 1 alpha, and glycoprotein synthase kinase $3 \beta$ (GSK3 $\beta$ ) (118), which phosphorylate and direct $\beta$-catenin to proteasome degradation. APC mediates and regulates multiple processes, such as cell migration
(190), cell adhesion (41), cell proliferation (9), and cell death (38), as well as DNA replication and repair (54). Araki et al. found that activation and overexpression of wild-type APC decrease $C O X 2 \mathrm{mRNA}$ in the human colorectal cancer cell line by reducing $\beta$-catenin/T cell factor 4 (Tcf- 4 ) binding to the Tcf- 4 binding element (TBE) in the COX2 promoter and this is dependent on K-Ras activation (4).

In 1996, Oshima et al. showed for the first time the relationship between the COX2 and colorectal cancer development using a mouse model of familial adenomatous carcinoma (125). The suppression of COX2 activity either by use of a COX2 inhibitor or by gene knockout decreases the number and size of intestinal polyps in the familial adenomatous polyposis mouse, an APC ${ }^{\Delta 716}$ mouse model (125). The increased COX2 expression at sites of inflammation together with augmentation of NOS2 expression could suggest a protumorigenic collaboration between these pathways, which may act in parallel or be redundant in cancer progression.

The regulation of induction of human NOS2 by the transcription factors $\mathrm{NF} \kappa \mathrm{B}$ and Stat 1 is complex, often being cell specific. For example, Ganster et al. showed that in a human fibroblast cell line, the addition of IFN $\gamma$ represses the 
induction of NOS2 transcription by $\mathrm{NF} \kappa \mathrm{B}$ via activation of STAT1 and deletion of STAT1 restores NOS2 expression (49). However, IFN $\gamma$ has been shown to independently induce NOS2 mRNA in other cancer cells indicating a different regulation of NOS2 in different tumors $(60,170)$.

Du et al. proposed that cytokine induction of NOS2 depends on the Wnt/APC pathway (36). $\beta$-catenin can bind to the TBE in the promoter region of human NOS2, thus increasing its expression in different cell lines, including colon cancer cell lines (35). However, other studies have shown that some cancer cell lines have decreased NOS2 expression when incubated with cytokine mixtures $(36,76)$. This opposite effect was attributed to the overexpression of $\beta$-catenin in some colon cancer cell lines in which the $A P C$ gene was defective, leading to inhibition of $\mathrm{NF} \kappa \mathrm{B}$ activity and diminished NOS2 expression. The response to cytokines was rescued by overexpressing wild-type APC, leading to decreased $\beta$-catenin and increased NOS2 expression $(35,36)$. Thus, induction of NOS2 can be cell genotype dependent as well.

Recently, Xia et al. showed that NFKB is a potent transcriptional suppressor of protein tensin homolog (PTEN) (191). PTEN is a protein phosphatase that negatively regulates phosphatidylinositol 3 kinase (PI3K)/protein kinase B (Akt) signaling. Thus, the loss of PTEN increases Akt phosphorylation, which in turn decreases GSK3 $\beta$ levels, thus increasing $\beta$-catenin that can serve to augment NOS2 expression. On the contrary, Shaked et al. found that constant activation of $\mathrm{NF} \kappa \mathrm{B}$ by overexpression of $\operatorname{IK} \beta$ kinase beta (IKKB) in mouse intestinal epithelium accelerates $A P C$ gene loss due to increased $\mathrm{NO}$ generation related to NOS2 overexpression (151). IK $\beta$ is the inhibitory effector of $N F \kappa B$ that confines it to the cytoplasm, thus preventing its migration to the nucleus where it participates in the transcriptional control of multiple genes (>150) (126). IKKB phosphorylates IK $\beta$ and frees $\mathrm{NF} \kappa \mathrm{B}$.

Colorectal cancer development and progress are associated with changes in important cell signaling pathways like the Wnt pathway $(37,73)$, Notch pathway (179), and PI3K/mammalian target of rapamycin (mTOR)/Akt pathway $(55,78)$. Despite somatic mutations found in cancers, activation of PI3K pathway can also occur by extra cellular stimuli, via receptor tyrosine kinases, or by stimulation from activated Ras (178). Furthermore, NO can stimulate the Ras/Raf1/MEK/ERK1/2 pathway and promote cell cycle progression (31).

It has been shown recently in colorectal clinical trials with drugs that interfere with PI3K-mTOR pathway extends overall patient survival (127). In response to nutrient availability, the mTOR pathway regulates multiple intracellular processes, such as cell cycle and proliferation, survival, protein synthesis, and actin organization (10). Proteins that belong to mTOR complex 1 (mTORC1) and mTOR complex 2 (mTORC2), and p-Akt (Ser473 one of the downstream targets of mTOR), have been found to be overexpressed in human colorectal cancers (55). The use of rapamycin, an inhibitor of mTOR, or genetic knockdown of the expression of raptor, a component of mTORC1, or knockdown of the expression of rictor, a component of mTORC2, decreases cancer cell migration and invasion. In addition, inhibition of mTOR modulates the expression of proteins associated with the mesenchymal-epithelial transition, E-cadherin, and decreases vimentin, smooth muscle actin, fibronectin, and matrix metalloproteinase 9 (MMP9) (55).
In rodents, inhibitors of the PI3K-mTOR pathway decrease cytokine-induced NOS2 expression in mouse macrophages (145). Lisi et al. showed that rapamycin also decreases NOS2 mRNA stability in astrocytes (97). Furthermore, recent studies have shown that mTOR regulates hypoxia-induced NOS2 expression in microglia (101). However, more studies are necessary to understand the mechanism by which mTOR regulates NOS2 in humans.

Besides biological endogenous production, $\mathrm{NO}$ can be delivered exogenously via the breakdown of compounds known as NO donors. These compounds have been helpful in elucidating the mechanisms of NOS-related pathways in cell physiology and pathology. Thomas et al. showed that incubation of cells with a range of concentrations of an exogenous NO donor leads to concentration- and time-dependent cell signaling (172). NO concentrations $<50 \mathrm{n} M$ are associated with activation of guanosine $3^{\prime} 5^{\prime}$ cyclic monophosphate (cGMP)-dependent cell signaling pathways in physiological conditions. These include pathways involved in the regulation of vascular tone; concentrations between 50 and $300 \mathrm{n} M$ are associated with activation of ERK, AKT, hypoxiainducible factor $1 \alpha(\mathrm{HIF} 1 \alpha)$, and p53 signaling; and concentrations higher than $300 \mathrm{n} M$ elicit signaling associated with nitrosative stress (173).

The transcription factor HIF $1 \alpha$ has an important role in adaptation of tumors to hypoxia. Under normoxia, HIF $1 \alpha$ is hydroxylated by prolyl hydroxylase domain enzymes (PHDs) and targeted for proteasomal degradation (143). PHDs are dioxygenases dependent on 2-oxoglutarate and iron and they have $\mathrm{O}_{2}$-dependent activity. PHDs are also sensitive to competitive inhibition by some citric acid cycle metabolites known to accumulate in some cancer types, such as succinate and fumarate. Decreased levels of 2-oxoglutarate due to mutations in isocitrate dehydrogenases also decrease the activity of PHDs (135). Therefore, HIF1 $\alpha$ can be stabilized under hypoxic conditions and normoxic conditions via accumulation of citric acid metabolites.

HIF $1 \alpha$ plays a role in a metabolic change observed in tumorigenesis by regulating mitochondrial metabolism, mitochondrial biogenesis, and mitophagy (149). It also regulates the expression of glucose transporters and lactate dehydrogenase (108). NO modification of the nonheme iron protein leads to stabilization of HIF1 $\alpha$. This mechanism is a major component of HIF1 $\alpha$ stabilization and signaling via NO. Moreover, HIF $1 \alpha$ protein is a target of $S$-nitrosation, which may further enhance its stability and signaling (164). NO can modulate HIF $1 \alpha$ function and its role changes according to the availability of $\mathrm{O}_{2}$. Under normoxia, endogenous $\mathrm{NO}$ or exogenous NO donors can lead to HIF1 $\alpha$ accumulation. In contrast, under hypoxia, NO attenuates HIF1 $\alpha$ accumulation (15). Increased stabilization of HIF $1 \alpha$ in turn can lead to increased vascular endothelial growth factor (VEGF) production, angiogenesis, and metabolic changes.

NO activates soluble guanylate cyclase to produce cGMP in different tissues (5). The level of this second messenger has an important role to play in cell physiology. cGMP plays a critical role in regulating normal GI function $(88,103)$. Colorectal cGMP-dependent protein kinase (PKG) expression levels are decreased in samples from colorectal cancer patients and its overexpression in colon carcinoma cells decreases tumor growth and invasiveness in nude mouse models (64). Furthermore, some studies have shown that 
PKG1 downregulates $\beta$-catenin (92) and in metastatic colon carcinoma decreases tumor angiogenesis (91), inhibits cell migration, and increases apoptosis $(32,175)$, possibly due to a concurrent decrease in NOS2 expression.

Degradation of the extracellular matrix is associated with tumor invasion and metastasis. This process is mediated by endopeptidases called MMPs (14). These enzymes are capable of digesting components of the extracellular matrix, including collagens, laminins, fibronectin, and proteoglycans (123). Increased expression levels of MMP-2 and MMP-9 are associated with poor survival outcome in colorectal cancer $(17,144)$. The activity of MMP is dependent on removal of $\mathrm{Zn}$-thiolate, which leads to a conformational protein change that allows substrate binding. NO can regulate expression of MMPs and their endogenous inhibitor tissue inhibitor matrix metalloproteinase by changing the level of the NO second messenger cGMP. NO and RNS can also disrupt the zinccysteine in MMPs, leading to their activation (138). Babykutty et al. found that activation of MMP-2/9 is accompanied by increased expression of Rho and Rac 1 and phosphorylation of Erk-1/2 (8). The activation of this signaling axis results in stimulation of colon cancer cell migration and invasion. Furthermore, MMP activation releases $\beta$-catenin from interactions with E-cadherin, leading to translocation of $\beta$-catenin to the nucleus, where it can activate the transcription of genes, including NOS2 (99).

The relationship between NO, COX2, and tumor survival is not always linear. Liu et al. found that human colon cancer cells incubated in the presence of S-nitroglutathione increase both COX2 expression and PGE2 in a dose- and timedependent manner, although they inhibit the growth of cells (98). Furthermore, the metastatic human colon cancer cell line SW620 when incubated in the presence of an NO donor was more sensitive to proapoptotic treatment through induction apoptosis-inducing factor $(A I F)$ and protein expression, suggesting a mitochondrial apoptotic pathway associated with this process (65).

The processes associated with colorectal tumor initiation and progressions are complex and associated with diverse cell signaling pathways. NOS2 and its product NO play a role in many cellular responses, including inflammation, genomic changes, tumor development, and prognosis. The mechanisms associated with these changes are not clearly understood and are summarized in Figure 5.

\section{Inflammatory bowel disease}

Chronic, remittent, or progressive inflammation of colon and rectum is classified as IBD, and this includes $\mathrm{CD}$ and $\mathrm{UC}$. $\mathrm{CD}$ may affect the entire GI tract, whereas UC is related to inflammation of the colonic mucosa (83). IBD, being derived from a chronic inflammatory process, is associated with increased risk of colon cancer (158).

The increase of both forms of IBD is associated with multiple factors, including genetic susceptibility, and environmental factors such as microbial flora and immune dysregulation (83). Very early onset inflammatory bowel disease (VEO-IBD) is described as IBD in children under the age of 10 years. Dhillon et al. found that NOS2 has increased activity in VEO-IBD associated with a NOS2 variant (33).

Studies conducted in the early 1990s with samples from patients suffering from IBD showed increased activity of
NOS2 (12), levels of its substrate, L-arginine, and product, citrulline in UC, (112). Other studies showed increased luminal NO gas sampled from patients with UC (102) and increased NOS2 mRNA, NOS2 protein expression, and nitrotyrosine marker in both UC and CD (155).

Hofseth et al. showed that colon tissues from patients with colon cancer-prone chronic inflammatory disease had increased phosphorylated and total p53 associated with increases in NOS2 expression. Furthermore, they showed that $\mathrm{NO}$ derived from decomposition of $\mathrm{NO}$ donors promotes DNA damage, phosphorylation, and accumulation of p53 (62). Moreover, tissues from patients with UC and CD had shown increased macrophage infiltration associated with increased inflammation (158). The increase in general inflammation and prolonged increase in NO concentrations contribute to the rise and development of colon cancer.

\section{Gastric Cancer}

The American Cancer Society estimated more than 26,000 new cases of gastric cancer and 10,700 deaths resulting from this disease in 2016 (153). The majority of gastric cancers are adenocarcinomas, that is, it begins in glandular cells responsible for the release of mucus and other fluids. The etiology of gastric cancer is unknown, but several risk factors have been associated with the development of this disease, including advanced age, male gender, diet, gastric adenomatous polyps, chronic inflammation, family history of gastric cancer, and Helicobacter pylori infection.

One of the strong risk factors in the development of gastric cancer is $H$. pylori infection, which affects more than half of the world's human population (51). H. pylori is a gramnegative bacterium and it has in its outer membrane LPS, which can interact with Toll-like receptors (TLRs) leading to initiation of innate immune responses. Inflammation caused by infection with $H$. pylori has an important role in development and progress of gastric and esophageal cancers. Approximately $10 \%$ of infections are associated with the development of peptic ulcers, chronic atrophic gastritis, gastric cancers, or mucosa-associated lymphoid tumors (58).

Gastric epithelium expresses TLR5 and TLR4 (148) that can recognize different components from $H$. pylori and initiate multiple cell signaling responses against the infection. H. pylori, through activation of TLR4, which has a site that recognizes LPS as a ligand, can induce the expression of host inflammatory genes, such as $T N F \alpha$, which in turn activate $N F \kappa B$ leading to increased COX2 and NOS2 expression (84). $H$. pylori infection also augments proliferation associated with activation of MEK1/2-ERK1/2 pathway (196) and Rasmediated activation of AP-1, a transcription factor associated with regulation of COX2 and NOS2 expression (26). Furthermore, levels of NOS2 and nitrotyrosine in the gastric mucosa are significantly higher in $H$. pylori-positive than in $H$. pylori-negative patients (53) with gastric cancer, showing that high NOS2 is an important determinant of carcinogenesis of gastric cancer following $H$. pylori infection.

$\mathrm{NO}$ has an important role in normal gastric function by controlling gastric blood flow and maintenance of gastric mucosal barrier integrity (105). NO controls the gastric blood flow through the activation of its second messenger cGMP. Changes in NO generation and NOS expression driven by various agents have been associated with gastric cancer onset 


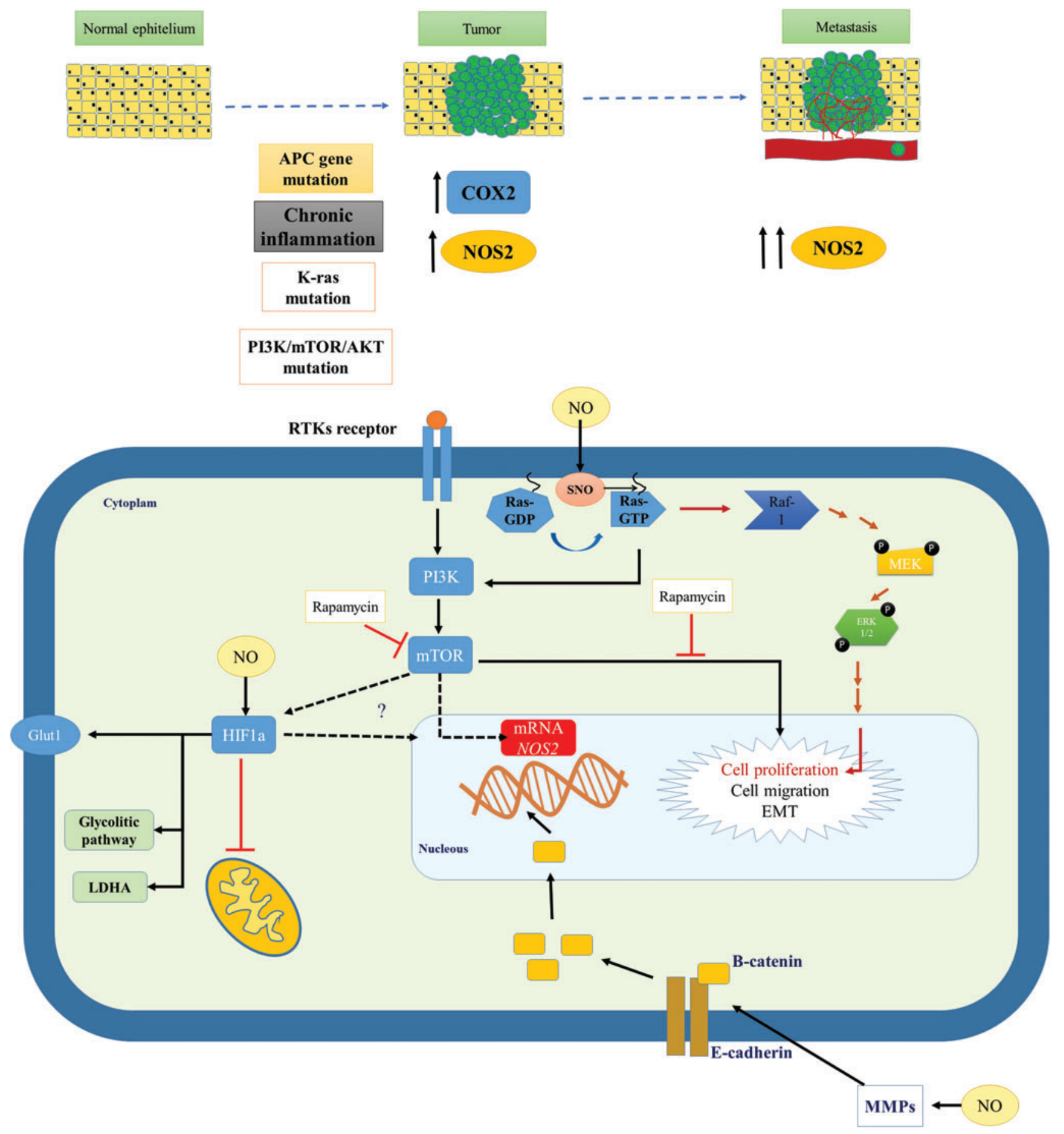

FIG. 5. NOS2 and colorectal cancer progression. Chronic inflammation is associated with increased levels of COX2, NOS2, and generation of NO. Hereditary and NO-associated mutations in the APC gene, $K$-Ras, and genes associated with $\mathrm{PI} 3 \mathrm{~K} / \mathrm{mTOR} / \mathrm{Akt}$ can lead to tumor development and metastasis. Activation cell signaling pathways by extracellular stimulus or by NO is associated with increased NOS2 mRNA expression, cell proliferation, and cell migration. NO can activate MMPs, disrupt proteins associated with cell adhesion, and increase $\beta$-catenin accumulation in nucleus following by induction of NOS2. Akt, protein kinase B; APC, adenomatous polyposis coli; COX, cyclooxygenase; MMP, matrix metalloproteinase; mTOR, mammalian target of rapamycin; PI3K, phosphatidylinositol 3 kinase. To see this illustration in color, the reader is referred to the web version of this article at www.liebertpub.com/ars 
and progression $(21,133)$. Mutations within the NOS2 gene or its promoter are associated with NOS induction and correlate with increased rates of cancer, including gastric cancer $(80,152)$, colorectal cancer (47), and esophageal cancer (43).

Studies of resected tumors showed a correlation with increased NOS2 expression and reductions in patient survival (197) and disease stage (184). Furthermore, NOS2 expression was associated with increased metastasis and angiogenesis in patients with gastric cancer (160). Zhang et al. showed that in over $50 \%$ of gastric cancer patients, increased NOS2 expression was associated with elevated rates of lymph node metastasis, vascular invasion, distant metastasis, and tumor node metastasis stage (197). Moreover, NOS2 is also associated with increased density of intratumor microvessels and angiogenesis in gastric cancer $(67,161)$. In addition, NOS2 has been shown to be positively correlated to lymphangiogenesis and lymphatic metastasis in gastric cancer (82).

\section{GI microbiota and cancer}

Microbiota participate in the production of $\mathrm{NO}$ from $\mathrm{NO}_{2}^{-}$ and $\mathrm{NO}_{3}^{-}$and may act in the control of blood pressure and cardiovascular health (66). Furthermore, the GI microbiota also has an important role in digestion of food, development of resistance against pathogens, development of mucosaassociated lymphoid tissue, and in overall systemic immune homeostasis (93).

Recent studies have shown a relationship between pretumor microbiota composition and development of gastric cancer. Interestingly, some studies found differences in microbiota composition between healthy subjects and patients affected by digestive diseases $(7,194)$. Furthermore, chronic $H$. pylori infection can shift the gastric microbiota by altering stomach pH. Besides H. pylori, other bacteria, such as Escherichia coli, Fusobacterium nucleatum, and Bacteroides fragilis, are associated with colon cancer pathogenesis (129). Presence of bacteria can change the GI tumor microenvironment, thus effecting the carcinogenic process. E. coli colonization of tumor can influence the protumor activity of macrophages by sustaining increased levels of COX2 expression (136). Furthermore, commensal microbiota can modulate the tumor response by altering the levels of cytokine (TNF) production by myeloid cells within the tumor (68). Commensal microorganisms are important regulators of the immune system and inflammation and may be addressed in therapies for cancer treatment (156).

\section{Esophageal Adenocarcinoma}

In 2016, the American Cancer Society estimated more than 16,900 new cases and 15, 600 deaths associated with esophageal cancer in the United States (153). The majority of esophageal adenocarcinomas arise from Barrett's metaplasia, in which reflux-damaged esophageal cells are replaced by mucus-secreting columnar cells (162). Changes in microbial flora were found in patients with esophageal cancer (40), including infection by human papillomavirus (183) and Epstein-Barr virus (192). In South America, a study found relationships with increased fungal infection (176). In contrast, other studies showed a relationship between inflammatory disorders after cancer treatment and increases in fungus infections, such as candidiasis $(95,142)$. Either way, these studies suggest an important role for the microbiome in esophageal cancer. In fact, new studies have shown changes in the distant esophageal microbiome in Barrett's esophagus (BE) and gastroesophageal reflux from an oropharyngeal-like microbiome to a more distinct microbiome with increased levels of gram-negative bacteria (157). Chen et al. found that specific changes in the salivary microbiota are also associated with increased rates of esophageal squamous cell carcinoma (24).

Gastroesophageal reflux disease (GERD) is one of the most common chronic diseases affecting up to $20 \%$ of United States population (115). BE is a complication of GERD that affects $\sim 10 \%$ of patients with GERD and that increases the predisposition for esophageal cancer (74).

NOS2 expression is increased in all associated stages of disease: GERD (96), adenoma (186), and esophageal carcinoma (110). The evolution of metaplasia to adenocarcinoma is associated with inflammatory processes and augmented the production of PGE2, COX2 mRNA, and COX2 protein expression $(130,186)$.

Esophageal cancers also show increased expression (23) and mutation of p53 (63). A recent article showed that esophageal squamous cell carcinoma (ESCC) is associated with decreased content of long noncoding RNAs (lncRNAs) in tumor of patients. Furthermore, overexpression of lncRNA in ESCC cell line induces apoptosis and inhibits proliferation and invasion by regulating the activation of p53 (182).

The Mutated in Colon Cancer $(M C C)$ gene mutation is implicated in sporadic colorectal cancer and located in the same chromosome region as APC. Boynton et al. found that deletions of one allele of the tumor suppressor gene APC and/ or MCC occur in more than $75 \%$ of analyzed samples from patients with esophageal cancer (13). Furthermore, the loss of heterozygosity at the $A P C$ and $M C C$ loci was also found in patients with primary breast carcinoma (111), indicating that this type of tumor could share same pathways and mechanisms seen in esophageal and colorectal cancer.

The transcription factor HIF1 $\alpha$ was found increased in esophageal carcinoma (109). Furthermore, some studies had shown a direct correlation between increases in HIF1 $\alpha$, VEGF (85), and NOS2 (167) in squamous cell carcinoma from samples of patients with esophageal cancer. Moreover, increased VEGF is associated with deep invasion in esophageal carcinoma (167).

\section{Liver Cancer}

Liver cancer includes $\mathrm{HCC}$ and intrahepatic bile duct cancer. Worldwide, 700,000 new cases were diagnosed at 2008 (44). The American Cancer Society estimates more than 39,000 new cases of liver cancer just within the United States. The major cause of HCC in Asia and sub-Saharan Africa is infection by hepatitis B virus (HBV), where HBV accounts for more than $70 \%$ of all cases. The risk factor associated with development of HCC in North America, Europe, and Japan is with hepatitis C virus (HCV), which accounts for 50$70 \%$ of cases (44).

Nitrosamines that are metabolized by liver P450 enzymes were shown to be powerful carcinogens in rodent models through alkylation of DNA. $\mathrm{NO}_{2}^{-}$derived from different food sources in the stomach can nitrosate different compounds resulting in nitrosamine formation. The advent of the discovery of NO generation by immune cells substantially 
FIG. 6. Role of NOS2 in gastrointestinal cancer. Chronic inflammation is associated with increased $\mathrm{COX} 2$ and NOS2 enzymes and development of gastrointestinal cancers. Increased levels of NO can lead to DNA mutations in targets such as p53. Augmented NO generation is also associated with angiogenesis and metastasis $(22,48$, 140) leading to poor patient survival. ACF, aberrant crypt foci; BE, Barrett's esophagus; GERD, gastroesophageal reflux disease; HBV, hepatitis B virus; $\mathrm{HCV}$, hepatitis $\mathrm{C}$ virus; IBD, Inflammatory bowel disease; NCP, noncancerous polyps. To see this illustration in color, the reader is referred to the web version of this article at www.liebertpub.com/ars
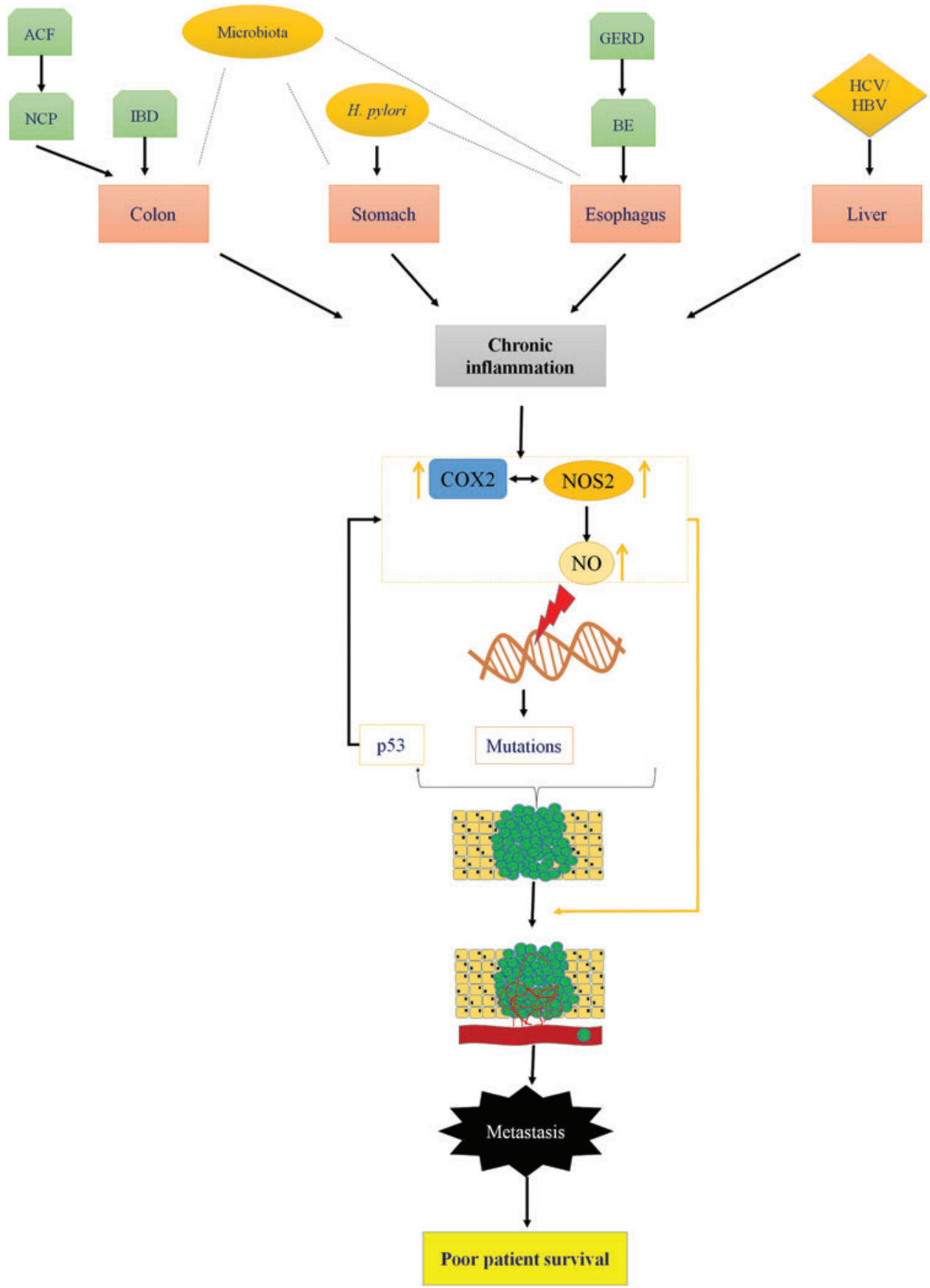

In liver tumor, several studies have shown that NOS2 is present and correlated with HIF1 $\alpha$ expression and increased oxidative damage. Some studies have shown a relationship between hepatocellular cancer severity and elevated NOS2 and COX2 expression $(69,134)$. Increased NOS2 is also correlated with poor outcome (134).

$\mathrm{HCC}$ is usually associated with vascular invasion and metastasis due to the high vascularization of this tissue. NOS2 has been shown to induce the activity of $\mathrm{COX} 2$, which has been proposed to increase vessel density in other cancer types $(79,197)$. These studies also suggest that NOS2 is associated with increased metastasis. Sun et al. showed that resected tissue from patients with hepatocellular cancer had increased level of MMP9 associated with increased 
expression of NOS2 (165). Although there is little predictive value of NOS2 and COX2 in HCC, in cancers initiated from $\mathrm{HCV}$ and HBV, these are predictive of poor outcome, suggesting that there is causal relationship. Generally, liver cancer is discovered at an advanced stage, suggesting that multiple factors can be driving the tumor.

\section{Conclusions}

Chronic inflammation plays a key role in initiation and progression of GI cancers. NOS2 and COX2 are important mediators of inflammation-driven cancer progression. The role of COX2 in various GI cancers is well established and NSAIDs have been shown to be a viable chemopreventive option. Recent observations show that majority of patients with colon, gastric, esophageal, and liver cancers have elevated expression of NOS2 in their lesions as well. Furthermore, NOS/NO levels are often associated with increased metastasis, leading to poor patient prognosis. The association of elevated NOS2 expression with cancers arising due to bacterial, viral, and fungal infections suggests an important relationship of the same with tumor immune response and chronic inflammation. The cross talk between NOS2 and COX2 may increase risk and determine patient survival (Fig. 6).

\section{Acknowledgments}

This research was supported, in part, by the Intramural Research Program of the NIH, Cancer and Inflammation Program. G.A.d.O. is supported by the program Science Without Borders-CNPq process number 205342/2014-0.

\section{References}

1. Albakri QA and Stuehr DJ. Intracellular assembly of inducible NO synthase is limited by nitric oxide-mediated changes in heme insertion and availability. $J$ Biol Chem 271: 5414-5421, 1996.

2. Ambs S, Hussain SP, and Harris CC. Interactive effects of nitric oxide and the p53 tumor suppressor gene in carcinogenesis and tumor progression. FASEB $J$ 11: 443-448, 1997.

3. Ambs S, Merriam WG, Bennett WP, Felley-Bosco E, Ogunfusika MO, Oser SM, Klein S, Shields PG, Billiar TR, and Harris CC. Frequent nitric oxide synthase-2 expression in human colon adenomas: implication for tumor angiogenesis and colon cancer progression. Cancer Res 58: 334-341, 1998.

4. Araki Y, Okamura S, Hussain SP, Nagashima M, He P, Shiseki M, Miura K, and Harris CC. Regulation of cyclooxygenase- 2 expression by the Wnt and ras pathways. Cancer Res 63: 728-734, 2003.

5. Arnold WP, Mittal CK, Katsuki S, and Murad F. Nitric oxide activates guanylate cyclase and increases guanosine $3^{\prime}: 5^{\prime}$-cyclic monophosphate levels in various tissue preparations. Proc Natl Acad Sci U S A 74: 3203-3207, 1977.

6. Arthur JF. Structure and significance of metaplastic nodules in the rectal mucosa. J Clin Pathol 21: 735-743, 1968.

7. Aviles-Jimenez F, Vazquez-Jimenez F, Medrano-Guzman R, Mantilla A, and Torres J. Stomach microbiota composition varies between patients with non-atrophic gastritis and patients with intestinal type of gastric cancer. Sci Rep 4: 4202, 2014.
8. Babykutty S, Suboj P, Srinivas P, Nair AS, Chandramohan $\mathrm{K}$, and Gopala S. Insidious role of nitric oxide in migration/invasion of colon cancer cells by upregulating MMP-2/9 via activation of cGMP-PKG-ERK signaling pathways. Clin Exp Metastasis 29: 471-492, 2012.

9. Baeg GH, Matsumine A, Kuroda T, Bhattacharjee RN, Miyashiro I, Toyoshima K, and Akiyama T. The tumour suppressor gene product APC blocks cell cycle progression from G0/G1 to $\mathrm{S}$ phase. EMBO J 14: 5618-5625, 1995.

10. Benjamin D, Colombi M, Moroni C, and Hall MN. Rapamycin passes the torch: a new generation of mTOR inhibitors. Nat Rev Drug Discov 10: 868-880, 2011.

11. Bing RJ, Miyataka M, Rich KA, Hanson N, Wang X, Slosser HD, and Shi SR. Nitric oxide, prostanoids, cyclooxygenase, and angiogenesis in colon and breast cancer. Clin Cancer Res 7: 3385-3392, 2001.

12. Boughton-Smith NK, Evans SM, Hawkey CJ, Cole AT, Balsitis M, Whittle BJ, and Moncada S. Nitric oxide synthase activity in ulcerative colitis and Crohn's disease. Lancet 342: 338-340, 1993.

13. Boynton RF, Blount PL, Yin J, Brown VL, Huang Y, Tong Y, McDaniel T, Newkirk C, Resau JH, Raskind WH, Haggitt RC, Reid BJ, and Meltzer SJ. Loss of heterozygosity involving the APC and MCC genetic loci occurs in the majority of human esophageal cancers. Proc Natl Acad Sci U S A 89: 3385-3388, 1992.

14. Brinckerhoff CE, Rutter JL, and Benbow U. Interstitial collagenases as markers of tumor progression. Clin Cancer Res 6: 4823-4830, 2000.

15. Brune B and Zhou J. The role of nitric oxide (NO) in stability regulation of hypoxia inducible factor-1alpha (HIF-1alpha). Curr Med Chem 10: 845-855, 2003.

16. Bryan NS, Alexander DD, Coughlin JR, Milkowski AL, and Boffetta P. Ingested nitrate and nitrite and stomach cancer risk: an updated review. Food Chem Toxicol 50: 3646-3665, 2012.

17. Buhmeida A, Bendardaf R, Hilska M, Collan Y, Laato M, Syrjanen S, Syrjanen K, and Pyrhonen S. Prognostic significance of matrix metalloproteinase-9 (MMP-9) in stage II colorectal carcinoma. J Gastrointest Cancer 40: 91-97, 2009.

18. Carethers JM and Jung BH. Genetics and genetic biomarkers in sporadic colorectal cancer. Gastroenterology 149: 1177-1190 e3, 2015.

19. Caspari T. How to activate p53. Curr Biol 10: R315R317, 2000.

20. Casper I, Nowag S, Koch K, Hubrich T, Bollmann F, Henke J, Schmitz K, Kleinert H, and Pautz A. Posttranscriptional regulation of the human inducible nitric oxide synthase (iNOS) expression by the cytosolic poly(A)-binding protein (PABP). Nitric Oxide 33: 6-17, 2013.

21. Chang CS, Chen WN, Lin HH, Wu CC, and Wang CJ. Increased oxidative DNA damage, inducible nitric oxide synthase, nuclear factor kappaB expression and enhanced antiapoptosis-related proteins in Helicobacter pyloriinfected non-cardiac gastric adenocarcinoma. World $J$ Gastroenterol 10: 2232-2240, 2004.

22. Chen CN, Hsieh FJ, Cheng YM, Chang KJ, and Lee PH. Expression of inducible nitric oxide synthase and cyclooxygenase- 2 in angiogenesis and clinical outcome of human gastric cancer. J Surg Oncol 94: 226-233, 2006.

23. Chen J, Wu F, Pei HL, Gu WD, Ning ZH, Shao YJ, and Huang J. Analysis of the correlation between P53 and 
Cox-2 expression and prognosis in esophageal cancer. Oncol Lett 10: 2197-2203, 2015.

24. Chen X, Winckler B, Lu M, Cheng H, Yuan Z, Yang Y, Jin L, and Ye W. Oral microbiota and risk for esophageal squamous cell carcinoma in a high-risk area of China. PLoS One 10: e0143603, 2015.

25. Chen YJ, Ching WC, Chen JS, Lee TY, Lu CT, Chou HC, Lin PY, Khoo KH, Chen JH, and Chen YJ. Decoding the s-nitrosoproteomic atlas in individualized human colorectal cancer tissues using a label-free quantitation strategy. J Proteome Res 13: 4942-4958, 2014.

26. Cho SO, Lim JW, Kim KH, and Kim H. Involvement of Ras and AP-1 in Helicobacter pylori-induced expression of COX-2 and iNOS in gastric epithelial AGS cells. Dig Dis Sci 55: 988-996, 2010.

27. Cianchi F, Cortesini C, Fantappie O, Messerini L, Sardi I, Lasagna N, Perna F, Fabbroni V, Di Felice A, Perigli G, Mazzanti R, and Masini E. Cyclooxygenase-2 activation mediates the proangiogenic effect of nitric oxide in colorectal cancer. Clin Cancer Res 10: 2694-2704, 2004.

28. Clementi E and Nisoli E. Nitric oxide and mitochondrial biogenesis: a key to long-term regulation of cellular metabolism. Comp Biochem Physiol A Mol Integr Physiol 142: 102-110, 2005.

29. Crawford LV, Pim DC, and Bulbrook RD. Detection of antibodies against the cellular protein p53 in sera from patients with breast cancer. Int J Cancer 30: 403-408, 1982.

30. da Costa PE, Batista WL, Curcio MF, Moraes MS, Borges RE, Nascimento PA, Travassos LR, and Monteiro HP. Protein tyrosine phosphatase alpha regulates cell detachment and cell death profiles induced by nitric oxide donors in the A431 human carcinoma cell line. Redox Rep 16: 27-37, 2011.

31. de Oliveira G, Rosa H, Reis A, Stern A, and Monteiro H. A role for nitric oxide and for nitric oxide synthases in tumor biology. For Immunopathol Dis Therap 3: 13, 2012.

32. Deguchi A, Thompson WJ, and Weinstein IB. Activation of protein kinase $\mathrm{G}$ is sufficient to induce apoptosis and inhibit cell migration in colon cancer cells. Cancer Res 64: 3966-3973, 2004.

33. Dhillon SS, Mastropaolo LA, Murchie R, Griffiths C, Thoni C, Elkadri A, Xu W, Mack A, Walters T, Guo C, Mack D, Huynh H, Baksh S, Silverberg MS, Brumell JH, Snapper SB, and Muise AM. Higher activity of the inducible nitric oxide synthase contributes to very early onset inflammatory bowel disease. Clin Transl Gastroenterol 5: e46, 2014.

34. This reference has been deleted.

35. Du Q, Park KS, Guo Z, He P, Nagashima M, Shao L, Sahai R, Geller DA, and Hussain SP. Regulation of human nitric oxide synthase 2 expression by Wnt beta-catenin signaling. Cancer Res 66: 7024-7031, 2006.

36. Du Q, Zhang X, Cardinal J, Cao Z, Guo Z, Shao L, and Geller DA. Wnt/beta-catenin signaling regulates cytokineinduced human inducible nitric oxide synthase expression by inhibiting nuclear factor-kappaB activation in cancer cells. Cancer Res 69: 3764-3771, 2009.

37. Duchartre Y, Kim YM, and Kahn M. The Wnt signaling pathway in cancer. Crit Rev Oncol Hematol 99: 141-149, 2016.

38. Eguren M, Porlan E, Manchado E, Garcia-Higuera I, Canamero M, Farinas I, and Malumbres M. The APC/C cofactor Cdh1 prevents replicative stress and p53- dependent cell death in neural progenitors. Nat Commun 4: 2880, 2013.

39. Erdman SE, Rao VP, Poutahidis T, Rogers AB, Taylor CL, Jackson EA, Ge Z, Lee CW, Schauer DB, Wogan GN, Tannenbaum SR, and Fox JG. Nitric oxide and TNF-alpha trigger colonic inflammation and carcinogenesis in Helicobacter hepaticus-infected, Rag2-deficient mice. Proc Natl Acad Sci U S A 106: 1027-1032, 2009.

40. Eslick GD. Infectious causes of esophageal cancer. Infect Dis Clin North Am 24: 845-852, vii, 2010.

41. Faux MC, Ross JL, Meeker C, Johns T, Ji H, Simpson RJ, Layton MJ, and Burgess AW. Restoration of full-length adenomatous polyposis coli (APC) protein in a colon cancer cell line enhances cell adhesion. J Cell Sci 117: 427-439, 2004.

42. Felley-Bosco E, Bender FC, Courjault-Gautier F, Bron C, and Quest AF. Caveolin-1 down-regulates inducible nitric oxide synthase via the proteasome pathway in human colon carcinoma cells. Proc Natl Acad Sci U S A 97: 14334-14339, 2000.

43. Ferguson HR, Wild CP, Anderson LA, Murphy SJ, Johnston BT, Murray LJ, Watson RG, McGuigan J, Reynolds JV, and Hardie LJ. Cyclooxygenase-2 and inducible nitric oxide synthase gene polymorphisms and risk of reflux esophagitis, Barrett's esophagus, and esophageal adenocarcinoma. Cancer Epidemiol Biomarkers Prev 17: 727-731, 2008.

44. Forner A, Llovet JM, and Bruix J. Hepatocellular carcinoma. Lancet 379: 1245-1255, 2012.

45. Forrester K, Ambs S, Lupold SE, Kapust RB, Spillare EA, Weinberg WC, Felley-Bosco E, Wang XW, Geller DA, Tzeng E, Billiar TR, and Harris CC. Nitric oxide-induced p53 accumulation and regulation of inducible nitric oxide synthase expression by wild-type p53. Proc Natl Acad Sci U S A 93: 2442-2447, 1996.

46. Forstermann U, Gath I, Schwarz P, Closs EI, and Kleinert H. Isoforms of nitric oxide synthase. Properties, cellular distribution and expressional control. Biochem Pharmacol 50: 1321-1332, 1995.

47. Fransen K, Elander N, and Soderkvist P. Nitric oxide synthase 2 (NOS2) promoter polymorphisms in colorectal cancer. Cancer Lett 225: 99-103, 2005.

48. Fukumura D, Kashiwagi S, and Jain RK. The role of nitric oxide in tumour progression. Nat Rev Cancer 6: 521-534, 2006.

49. Ganster RW, Taylor BS, Shao L, and Geller DA. Complex regulation of human inducible nitric oxide synthase gene transcription by Stat 1 and NF-kappa B. Proc Natl Acad Sci U S A 98: 8638-8643, 2001.

50. Glynn SA, Boersma BJ, Dorsey TH, Yi M, Yfantis HG, Ridnour LA, Martin DN, Switzer CH, Hudson RS, Wink DA, Lee DH, Stephens RM, and Ambs S. Increased NOS2 predicts poor survival in estrogen receptor-negative breast cancer patients. J Clin Invest 120: 3843-3854, 2010.

51. Gobert AP and Wilson KT. The immune battle against Helicobacter pylori infection: NO offense. Trends Microbiol 24: 366-376, 2016.

52. Goodwin DC, Landino LM, and Marnett LJ. Effects of nitric oxide and nitric oxide-derived species on prostaglandin endoperoxide synthase and prostaglandin biosynthesis. FASEB J 13: 1121-1136, 1999.

53. Goto T, Haruma K, Kitadai Y, Ito M, Yoshihara M, Sumii K, Hayakawa N, and Kajiyama G. Enhanced expression of inducible nitric oxide synthase and nitrotyrosine in gastric 
mucosa of gastric cancer patients. Clin Cancer Res 5: 1411-1415, 1999.

54. Greil C, Krohs J, Schnerch D, Follo M, Felthaus J, Engelhardt $\mathrm{M}$, and Wasch $\mathrm{R}$. The role of $\mathrm{APC} / \mathrm{C}$ in replication stress and origin of genomic instability. Oncogene 35: 3062-3070, 2016.

55. Gulhati P, Bowen KA, Liu J, Stevens PD, Rychahou PG, Chen M, Lee EY, Weiss HL, O'Connor KL, Gao T, and Evers BM. mTORC1 and mTORC2 regulate EMT, motility, and metastasis of colorectal cancer via RhoA and Rac1 signaling pathways. Cancer Res 71: 3246-3256, 2011.

56. Habibollahi P, Jamshidiha M, Daryani NE, Jahanzad I, Ghahremani $\mathrm{MH}$, and Ostad SN. Correlation between inducible nitric oxide synthase and cyclooxygenase-2 expression in human colorectal adenocarcinoma: a crosssectional study. Pathol Oncol Res 16: 327-335, 2010.

57. Hanada T, Kobayashi T, Chinen T, Saeki K, Takaki H, Koga K, Minoda Y, Sanada T, Yoshioka T, Mimata H, Kato S, and Yoshimura A. IFNgamma-dependent, spontaneous development of colorectal carcinomas in SOCS1deficient mice. J Exp Med 203: 1391-1397, 2006.

57a. Hao XP, Pretlow TG, Rao JS, and Pretlow TP. Inducible nitric oxide synthase (iNOS) is expressed similarly in multiple aberrant crypt foci and colorectal tumors from the same patients. Cancer Res 61: 419-422, 2001.

58. He C, Yang Z, and Lu N. Imbalance of gastrointestinal microbiota in the pathogenesis of Helicobacter pyloriassociated diseases. Helicobacter [Epub ahead of print]; DOI: 10.1111/hel.12297, 2016.

59. Heath CW, Jr., Thun MJ, Greenberg ER, Levin B, and Marnett LJ. Nonsteroidal antiinflammatory drugs and human cancer. Report of an interdisciplinary research workshop. Cancer 74: 2885-2888, 1994.

60. Heinecke JL, Ridnour LA, Cheng RY, Switzer CH, Lizardo MM, Khanna C, Glynn SA, Hussain SP, Young HA, Ambs $\mathrm{S}$, and Wink DA. Tumor microenvironment-based feedforward regulation of NOS2 in breast cancer progression. Proc Natl Acad Sci U S A 111: 6323-6328, 2014.

61. Hirohashi $\mathrm{S}$ and Sugimura T. Genetic alterations in human gastric cancer. Cancer Cells 3: 49-52, 1991.

62. Hofseth LJ, Saito S, Hussain SP, Espey MG, Miranda KM, Araki Y, Jhappan C, Higashimoto Y, He P, Linke SP, Quezado MM, Zurer I, Rotter V, Wink DA, Appella E, and Harris CC. Nitric oxide-induced cellular stress and p53 activation in chronic inflammation. Proc Natl Acad Sci U S A 100: 143-148, 2003.

63. Hollstein MC, Metcalf RA, Welsh JA, Montesano R, and Harris CC. Frequent mutation of the p53 gene in human esophageal cancer. Proc Natl Acad Sci U S A 87: 99589961, 1990.

64. Hou Y, Gupta N, Schoenlein P, Wong E, Martindale R, Ganapathy $\mathrm{V}$, and Browning D. An anti-tumor role for cGMPdependent protein kinase. Cancer Lett 240: 60-68, 2006.

65. Huerta S, Baay-Guzman G, Gonzalez-Bonilla CR, Livingston $\mathrm{EH}$, Huerta-Yepez S, and Bonavida B. In vitro and in vivo sensitization of SW620 metastatic colon cancer cells to CDDP-induced apoptosis by the nitric oxide donor DETANONOate: involvement of AIF. Nitric Oxide 20: 182-194, 2009.

66. Hyde ER, Luk B, Cron S, Kusic L, McCue T, Bauch T, Kaplan H, Tribble G, Petrosino JF, and Bryan NS. Characterization of the rat oral microbiome and the effects of dietary nitrate. Free Radic Biol Med 77: 249-257, 2014.
67. Ichinoe M, Mikami T, Shiraishi H, and Okayasu I. High microvascular density is correlated with high VEGF, iNOS and COX-2 expression in penetrating growth-type early gastric carcinomas. Histopathology 45: 612-618, 2004.

68. Iida N, Dzutsev A, Stewart CA, Smith L, Bouladoux N, Weingarten RA, Molina DA, Salcedo R, Back T, Cramer S, Dai RM, Kiu H, Cardone M, Naik S, Patri AK, Wang E, Marincola FM, Frank KM, Belkaid Y, Trinchieri G, and Goldszmid RS. Commensal bacteria control cancer response to therapy by modulating the tumor microenvironment. Science 342: 967-970, 2013.

69. Ikeguchi M, Ueta T, Yamane Y, Hirooka Y, and Kaibara $\mathrm{N}$. Inducible nitric oxide synthase and survivin messenger RNA expression in hepatocellular carcinoma. Clin Cancer Res 8: 3131-3136, 2002.

70. INCA INdCJAGdS. In: Estimate/2016-Cancer Incidence in Brazil, edited by VIGILÂNCIA CDPE. Rio de Janeiro, Brazil: INCA, 2015.

71. Inoue T, Fukuo K, Morimoto S, Koh E, and Ogihara T. Nitric oxide mediates interleukin-1-induced prostaglandin E2 production by vascular smooth muscle cells. Biochem Biophys Res Commun 194: 420-424, 1993.

72. Iwamuro M, Kawai Y, Matsumoto T, Uda M, and Okada H. Serum anti-p53 antibody as a tumour marker for colorectal cancer screening. Ecancermedicalscience 9: 560, 2015.

73. Jankowski JA, Bruton R, Shepherd N, and Sanders DS. Cadherin and catenin biology represent a global mechanism for epithelial cancer progression. Mol Pathol 50: 289-290, 1997.

74. Jankowski JA, Wright NA, Meltzer SJ, Triadafilopoulos G, Geboes K, Casson AG, Kerr D, and Young LS. Molecular evolution of the metaplasia-dysplasia-adenocarcinoma sequence in the esophagus. Am J Pathol 154: 965-973, 1999.

75. Janne PA and Mayer RJ. Chemoprevention of colorectal cancer. N Engl J Med 342: 1960-1968, 2000.

76. Jenkins DC, Charles IG, Baylis SA, Lelchuk R, Radomski MW, and Moncada S. Human colon cancer cell lines show a diverse pattern of nitric oxide synthase gene expression and nitric oxide generation. Br J Cancer 70: 847-849, 1994.

77. Jenkins DC, Charles IG, Thomsen LL, Moss DW, Holmes LS, Baylis SA, Rhodes P, Westmore K, Emson PC, and Moncada S. Roles of nitric oxide in tumor growth. Proc Natl Acad Sci U S A 92: 4392-4396, 1995.

78. Johnson SM, Gulhati P, Rampy BA, Han Y, Rychahou PG, Doan HQ, Weiss HL, and Evers BM. Novel expression patterns of $\mathrm{PI} 3 \mathrm{~K} / \mathrm{Akt} / \mathrm{mTOR}$ signaling pathway components in colorectal cancer. J Am Coll Surg 210: 767-776, 776-778, 2010.

79. Joo YE, Rew JS, Seo YH, Choi SK, Kim YJ, Park CS, and Kim SJ. Cyclooxygenase-2 overexpression correlates with vascular endothelial growth factor expression and tumor angiogenesis in gastric cancer. J Clin Gastroenterol 37: 28-33, 2003.

80. Jorge YC, Duarte MC, and Silva AE. Gastric cancer is associated with NOS2-954G/C polymorphism and environmental factors in a Brazilian population. BMC Gastroenterol 10: 64, 2010.

81. Kapil V, Khambata RS, Robertson A, Caulfield MJ, and Ahluwalia A. Dietary nitrate provides sustained blood pressure lowering in hypertensive patients: a randomized, phase 2, double-blind, placebo-controlled study. Hypertension 65: 320-327, 2015. 
82. Karadayi N, Kandemir NO, Yavuzer D, Korkmaz T, Gecmen $\mathrm{G}$, and Kokturk F. Inducible nitric oxide synthase expression in gastric adenocarcinoma: impact on lymphangiogenesis and lymphatic metastasis. Diagn Pathol 8: 151, 2013.

83. Kaser A, Zeissig S, and Blumberg RS. Inflammatory bowel disease. Апnи Rev Immunol 28: 573-621, 2010.

84. Kim JM, Kim JS, Jung HC, Oh YK, Chung HY, Lee CH, and Song IS. Helicobacter pylori infection activates NFkappaB signaling pathway to induce iNOS and protect human gastric epithelial cells from apoptosis. Am J Physiol Gastrointest Liver Physiol 285: G1171-G1180, 2003.

85. Kimura S, Kitadai Y, Tanaka S, Kuwai T, Hihara J, Yoshida K, Toge $\mathrm{T}$, and Chayama K. Expression of hypoxia-inducible factor (HIF)-1alpha is associated with vascular endothelial growth factor expression and tumour angiogenesis in human oesophageal squamous cell carcinoma. Eur J Cancer 40: 1904-1912, 2004.

86. Kleinert H, Pautz A, Linker K, and Schwarz PM. Regulation of the expression of inducible nitric oxide synthase. Eur J Pharmacol 500: 255-266, 2004.

87. Kleinert H, Schwarz PM, and Forstermann U. Regulation of the expression of inducible nitric oxide synthase. Biol Chem 384: 1343-1364, 2003.

88. Koh SD, Campbell JD, Carl A, and Sanders KM. Nitric oxide activates multiple potassium channels in canine colonic smooth muscle. J Physiol 489 (Pt 3): 735-743, 1995.

89. Kojima M, Morisaki T, Tsukahara Y, Uchiyama A, Matsunari Y, Mibu R, and Tanaka M. Nitric oxide synthase expression and nitric oxide production in human colon carcinoma tissue. J Surg Oncol 70: 222-229, 1999.

90. Kuper H, Adami HO, and Trichopoulos D. Infections as a major preventable cause of human cancer. J Intern Med 248: 171-183, 2000.

91. Kwon IK, Schoenlein PV, Delk J, Liu K, Thangaraju M, Dulin NO, Ganapathy V, Berger FG, and Browning DD. Expression of cyclic guanosine monophosphate-dependent protein kinase in metastatic colon carcinoma cells blocks tumor angiogenesis. Cancer 112: 1462-1470, 2008.

92. Kwon IK, Wang R, Thangaraju M, Shuang H, Liu K, Dashwood R, Dulin N, Ganapathy V, and Browning DD. PKG inhibits TCF signaling in colon cancer cells by blocking beta-catenin expression and activating FOXO4. Oncogene 29: 3423-3434, 2010.

93. Kyburz A and Muller A. The gastrointestinal tract microbiota and allergic diseases. Dig Dis 34: 230-243, 2016.

94. Lagares-Garcia JA, Moore RA, Collier B, Heggere M, Diaz F, and Qian F. Nitric oxide synthase as a marker in colorectal carcinoma. Am Surg 67: 709-713, 2001.

95. Lal DR, Foroutan HR, Su WT, Wolden SL, Boulad F, and La Quaglia MP. The management of treatment-related esophageal complications in children and adolescents with cancer. J Pediatr Surg 41: 495-499, 2006.

96. Lee JS, Oh TY, Ahn BO, Cho H, Kim WB, Kim YB, Surh YJ, Kim HJ, and Hahm KB. Involvement of oxidative stress in experimentally induced reflux esophagitis and Barrett's esophagus: clue for the chemoprevention of esophageal carcinoma by antioxidants. Mutat Res 480 481: 189-200, 2001.

97. Lisi L, Navarra P, Feinstein DL, and Dello Russo C. The mTOR kinase inhibitor rapamycin decreases iNOS mRNA stability in astrocytes. J Neuroinflammation 8: 1, 2011.

98. Liu Q, Chan ST, and Mahendran R. Nitric oxide induces cyclooxygenase expression and inhibits cell growth in colon cancer cell lines. Carcinogenesis 24: 637-642, 2003.
99. Liu Y, Borchert GL, and Phang JM. Polyoma enhancer activator 3, an ets transcription factor, mediates the induction of cyclooxygenase- 2 by nitric oxide in colorectal cancer cells. J Biol Chem 279: 18694-18700, 2004.

100. Liu Z, Cao AT, and Cong Y. Microbiota regulation of inflammatory bowel disease and colorectal cancer. Semin Cancer Biol 23: 543-552, 2013.

101. Lu DY, Liou HC, Tang $\mathrm{CH}$, and Fu WM. Hypoxiainduced iNOS expression in microglia is regulated by the $\mathrm{PI} 3-\mathrm{kinase} / \mathrm{Akt} / \mathrm{mTOR}$ signaling pathway and activation of hypoxia inducible factor-1alpha. Biochem Pharmacol 72: 992-1000, 2006.

102. Lundberg JO, Hellström PM, Lundberg JM, and Alving K. Greatly increased luminal nitric oxide in ulcerative colitis. Lancet 344: 1673-1674, 1994.

103. MacNaughton WK. Nitric oxide-donating compounds stimulate electrolyte transport in the guinea pig intestine in vitro. Life Sci 53: 585-593, 1993.

104. Magee PN. Cellular injury and chemical carcinogenesis by $N$-nitroso compounds. Cancer Prog 92: 56-66, 1963.

105. Magierowski M, Magierowska K, Kwiecien S, and Brzozowski T. Gaseous mediators nitric oxide and hydrogen sulfide in the mechanism of gastrointestinal integrity, protection and ulcer healing. Molecules 20: 9099-9123, 2015.

106. Maher SG and Reynolds JV. Basic concepts of inflammation and its role in carcinogenesis. Recent Results Cancer Res 185: 1-34, 2011.

107. Malilas W, Koh SS, Kim S, Srisuttee R, Cho IR, Moon J, Yoo HS, Oh S, Johnston RN, and Chung YH. Cancer upregulated gene 2, a novel oncogene, enhances migration and drug resistance of colon cancer cells via STAT1 activation. Int J Oncol 43: 1111-1116, 2013.

108. Marin-Hernandez A, Gallardo-Perez JC, Ralph SJ, Rodriguez-Enriquez S, and Moreno-Sanchez R. HIF1alpha modulates energy metabolism in cancer cells by inducing over-expression of specific glycolytic isoforms. Mini Rev Med Chem 9: 1084-1101, 2009.

109. Matsuyama T, Nakanishi K, Hayashi T, Yoshizumi Y, Aiko S, Sugiura Y, Tanimoto T, Uenoyama M, Ozeki Y, and Maehara T. Expression of hypoxia-inducible factorlalpha in esophageal squamous cell carcinoma. Cancer Sci 96: 176-182, 2005.

110. McAdam E, Haboubi HN, Forrester G, Eltahir Z, SpencerHarty S, Davies C, Griffiths AP, Baxter JN, and Jenkins GJ. Inducible nitric oxide synthase (iNOS) and nitric oxide (NO) are important mediators of reflux-induced cell signalling in esophageal cells. Carcinogenesis 33: 20352043, 2012.

111. Medeiros AC, Nagai MA, Neto MM, and Brentani RR. Loss of heterozygosity affecting the APC and MCC genetic loci in patients with primary breast carcinomas. Cancer Epidemiol Biomarkers Prev 3: 331-333, 1994.

112. Middleton SJ, Shorthouse M, and Hunter JO. Increased nitric oxide synthesis in ulcerative colitis. Lancet 341: 465-466, 1993.

113. Misko TP, Trotter JL, and Cross AH. Mediation of inflammation by encephalitogenic cells: interferon gamma induction of nitric oxide synthase and cyclooxygenase $2 . J$ Neuroimmunol 61: 195-204, 1995.

114. Moncada S and Higgs A. The L-arginine-nitric oxide pathway. N Engl J Med 329: 2002-2012, 1993.

115. Moore M, Afaneh C, Benhuri D, Antonacci C, Abelson J, and Zarnegar R. Gastroesophageal reflux disease: a review 
of surgical decision making. World J Gastrointest Surg 8: 77-83, 2016.

116. Moraes MS, Costa PE, Batista WL, Paschoalin T, Curcio MF, Borges RE, Taha MO, Fonseca FV, Stern A, and Monteiro HP. Endothelium-derived nitric oxide (NO) activates the NO-epidermal growth factor receptor-mediated signaling pathway in bradykinin-stimulated angiogenesis. Arch Biochem Biophys 558: 14-27, 2014.

117. Mori M. Regulation of nitric oxide synthesis and apoptosis by arginase and arginine recycling. J Nutr 137: 1616S-1620S, 2007.

118. Nakamura T, Hamada F, Ishidate T, Anai K, Kawahara K, Toyoshima K, and Akiyama T. Axin, an inhibitor of the Wnt signalling pathway, interacts with beta-catenin, GSK3 beta and APC and reduces the beta-catenin level. Genes Cells 3: 395-403, 1998.

119. Navarro-Lerida I, Corvi MM, Barrientos AA, Gavilanes F, Berthiaume LG, and Rodriguez-Crespo I. Palmitoylation of inducible nitric-oxide synthase at Cys-3 is required for proper intracellular traffic and nitric oxide synthesis. $J$ Biol Chem 279: 55682-55689, 2004.

120. Nisoli E, Tonello C, Cardile A, Cozzi V, Bracale R, Tedesco L, Falcone S, Valerio A, Cantoni O, Clementi E, Moncada S, and Carruba MO. Calorie restriction promotes mitochondrial biogenesis by inducing the expression of eNOS. Science 310: 314-317, 2005.

121. Norton SE, Dunn ET, McCall JL, Munro F, and Kemp RA. Gut macrophage phenotype is dependent on the tumor microenvironment in colorectal cancer. Clin Transl Immunol 5: e76, 2016.

122. Nozoe T, Yasuda M, Honda M, Inutsuka S, and Korenaga D. Immunohistochemical expression of cytokine induced nitric oxide synthase in colorectal carcinoma. Oncol Rep 9: 521-524, 2002.

123. O'Sullivan S, Medina C, Ledwidge M, Radomski MW, and Gilmer JF. Nitric oxide-matrix metaloproteinase-9 interactions: biological and pharmacological significance-NO and MMP-9 interactions. Biochim Biophys Acta 1843: 603-617, 2014.

124. Okamoto M, Sato C, Kohno Y, Mori T, Iwama T, Tonomura A, Miki Y, Utsunomiya J, Nakamura Y, White R, et al. Molecular nature of chromosome $5 \mathrm{q}$ loss in colorectal tumors and desmoids from patients with familial adenomatous polyposis. Hum Genet 85: 595-599, 1990.

125. Oshima M, Dinchuk JE, Kargman SL, Oshima H, Hancock B, Kwong E, Trzaskos JM, Evans JF, and Taketo MM. Suppression of intestinal polyposis in Apc delta716 knockout mice by inhibition of cyclooxygenase 2 (COX2). Cell 87: 803-809, 1996.

126. Pahl HL. Activators and target genes of Rel/NF-kappaB transcription factors. Oncogene 18: 6853-6866, 1999.

127. Papadatos-Pastos D, Rabbie R, Ross P, and Sarker D. The role of the PI3K pathway in colorectal cancer. Crit Rev Oncol Hematol 94: 18-30, 2015.

128. Parkin R, Waynfort.Hb, and Magee PN. Activity of some nitroso-compounds in mouse dominant-lethal mutation assay. Activity of $N$-nitroso- $N$-methylurea, " $N$-methyl- $N$ nitroso- $N$-nitroguanidine and $N$-nitrosomorpholine. Mutat Res 21: 155-161, 1973.

129. Perez-Chanona E and Trinchieri G. The role of microbiota in cancer therapy. Curr Opin Immunol 39: 75-81, 2016.

130. Piazuelo E, Jimenez $\mathrm{P}$, and Lanas A. COX-2 inhibition in esophagitis, Barrett's esophagus and esophageal cancer. Curr Pharm Des 9: 2267-2280, 2003.
131. Porter PL, Gown AM, Kramp SG, and Coltrera MD. Widespread p53 overexpression in human malignant tumors. An immunohistochemical study using methacarnfixed, embedded tissue. Am J Pathol 140: 145-153, 1992.

132. Puglisi MA, Cenciarelli C, Tesori V, Cappellari M, Martini M, Di Francesco AM, Giorda E, Carsetti R, RicciVitiani L, and Gasbarrini A. High nitric oxide production, secondary to inducible nitric oxide synthase expression, is essential for regulation of the tumour-initiating properties of colon cancer stem cells. J Pathol 236: 479-490, 2015.

133. Rafiei A, Hosseini V, Janbabai G, Fazli B, Ajami A, Hosseini-Khah Z, Gilbreath J, and Merrell DS. Inducible nitric oxide synthetase genotype and Helicobacter pylori infection affect gastric cancer risk. World J Gastroenterol 18: 4917-4924, 2012.

134. Rahman MA, Dhar DK, Yamaguchi E, Maruyama S, Sato T, Hayashi H, Ono T, Yamanoi A, Kohno H, and Nagasue N. Coexpression of inducible nitric oxide synthase and COX-2 in hepatocellular carcinoma and surrounding liver: possible involvement of COX-2 in the angiogenesis of hepatitis C virus-positive cases. Clin Cancer Res 7: 13251332, 2001.

135. Raimundo N, Baysal BE, and Shadel GS. Revisiting the TCA cycle: signaling to tumor formation. Trends $\mathrm{Mol}$ Med 17: 641-649, 2011.

136. Raisch J, Buc E, Bonnet M, Sauvanet P, Vazeille E, de Vallee A, Dechelotte P, Darcha C, Pezet D, Bonnet R, Bringer MA, and Darfeuille-Michaud A. Colon cancerassociated B2 Escherichia coli colonize gut mucosa and promote cell proliferation. World J Gastroenterol 20: 6560-6572, 2014.

137. Rao CV, Indranie C, Simi B, Manning PT, Connor JR, and Reddy BS. Chemopreventive properties of a selective inducible nitric oxide synthase inhibitor in colon carcinogenesis, administered alone or in combination with celecoxib, a selective cyclooxygenase- 2 inhibitor. Cancer Res 62: 165-170, 2002.

138. Ridnour LA, Windhausen AN, Isenberg JS, Yeung N, Thomas DD, Vitek MP, Roberts DD, and Wink DA. Nitric oxide regulates matrix metalloproteinase- 9 activity by guanylyl-cyclase-dependent and -independent pathways. Proc Natl Acad Sci U S A 104: 16898-16903, 2007.

139. Rizzo A, Pallone F, Monteleone G, and Fantini MC. Intestinal inflammation and colorectal cancer: a doubleedged sword? World J Gastroenterol 17: 3092-3100, 2011.

140. Roberts DD, Isenberg JS, Ridnour LA, and Wink DA. Nitric oxide and its gatekeeper thrombospondin-1 in tumor angiogenesis. Clin Cancer Res 13: 795-798, 2007.

141. Rumbo M, Courjault-Gautier F, Sierro F, Sirard JC, and Felley-Bosco E. Polarized distribution of inducible nitric oxide synthase regulates activity in intestinal epithelial cells. FEBS J 272: 444-453, 2005.

142. Saito H, Sueyama H, Fukuda T, and Ota K. Necrotising Candida oesophagitis after thoracic radiotherapy: significance of oesophageal wall oedema on CT. BMJ Case Rep 2015: pii: bcr2015210477, 2015.

143. Salceda S and Caro J. Hypoxia-inducible factor 1alpha (HIF-1alpha) protein is rapidly degraded by the ubiquitinproteasome system under normoxic conditions. Its stabilization by hypoxia depends on redox-induced changes. $J$ Biol Chem 272: 22642-22647, 1997.

144. Salem N, Kamal I, Al-Maghrabi J, Abuzenadah A, PeerZada AA, Qari Y, Al-Ahwal M, Al-Qahtani M, and 
Buhmeida A. High expression of matrix metalloproteinases: MMP-2 and MMP-9 predicts poor survival outcome in colorectal carcinoma. Future Oncol 12: 323-331, 2016.

145. Salh B, Wagey R, Marotta A, Tao JS, and Pelech S. Activation of phosphatidylinositol 3-kinase, protein kinase B, and p70 S6 kinases in lipopolysaccharide-stimulated Raw 264.7 cells: differential effects of rapamycin, Ly294002, and wortmannin on nitric oxide production. J Immunol 161: 6947-6954, 1998

146. Salvemini D, Misko TP, Masferrer JL, Seibert K, Currie MG, and Needleman P. Nitric oxide activates cyclooxygenase enzymes. Proc Natl Acad Sci U S A 90: 7240-7244, 1993.

147. Sander J and Burkle G. [Induction of malignant tumors in rats by simultaneous feeding of nitrite and secondary amines]. $Z$ Krebsforsch 73: 54-66, 1969 (Article in German).

148. Schmausser B, Andrulis M, Endrich S, Lee SK, Josenhans C, Muller-Hermelink HK, and Eck M. Expression and subcellular distribution of toll-like receptors TLR4, TLR5 and TLR9 on the gastric epithelium in Helicobacter pylori infection. Clin Exp Immunol 136: 521-526, 2004.

149. Schonenberger MJ and Kovacs WJ. Hypoxia signaling pathways: modulators of oxygen-related organelles. Front Cell Dev Biol 3: 42, 2015.

150. Scott N, Sagar P, Stewart J, Blair GE, Dixon MF, and Quirke P. p53 in colorectal cancer: clinicopathological correlation and prognostic significance. Br J Cancer 63: 317-319, 1991.

151. Shaked H, Hofseth LJ, Chumanevich A, Chumanevich AA, Wang J, Wang Y, Taniguchi K, Guma M, Shenouda S, Clevers H, Harris CC, and Karin M. Chronic epithelial NF-kappaB activation accelerates APC loss and intestinal tumor initiation through iNOS up-regulation. Proc Natl Acad Sci U S A 109: 14007-14012, 2012.

152. Shen J, Wang RT, Wang LW, Xu YC, and Wang XR. A novel genetic polymorphism of inducible nitric oxide synthase is associated with an increased risk of gastric cancer. World J Gastroenterol 10: 3278-3283, 2004.

153. Siegel RL, Miller KD, and Jemal A. Cancer statistics, 2016. CA Cancer J Clin 66: 7-30, 2016.

154. Simon PS, Sharman SK, Lu C, Yang D, Paschall AV, Tulachan SS, and Liu K. The NF-kappaB p65 and p50 homodimer cooperate with IRF8 to activate iNOS transcription. BMC Cancer 15: 770, 2015.

155. Singer II, Kawka DW, Scott S, Weidner JR, Mumford RA, Riehl TE, and Stenson WF. Expression of inducible nitric oxide synthase and nitrotyrosine in colonic epithelium in inflammatory bowel disease. Gastroenterology 111: 871-885, 1996.

156. Sivan A, Corrales L, Hubert N, Williams JB, AquinoMichaels K, Earley ZM, Benyamin FW, Lei YM, Jabri B, Alegre ML, Chang EB, and Gajewski TF. Commensal Bifidobacterium promotes antitumor immunity and facilitates anti-PD-L1 efficacy. Science 350: 1084-1089, 2015.

157. Snider EJ, Freedberg DE, and Abrams JA. Potential role of the microbiome in Barrett's esophagus and esophageal adenocarcinoma. Dig Dis Sci 61: 2217-2225, 2016.

158. Sohn JJ, Schetter AJ, Yfantis HG, Ridnour LA, Horikawa I, Khan MA, Robles AI, Hussain SP, Goto A, Bowman ED, Hofseth LJ, Bartkova J, Bartek J, Wogan GN, Wink DA, and Harris CC. Macrophages, nitric oxide and microRNAs are associated with DNA damage response pathway and senescence in inflammatory bowel disease. PLoS One 7: e44156, 2012.

159. Son HJ, Kim YH, Park DI, Kim JJ, Rhee PL, Paik SW, Choi KW, Song SY, and Rhee JC. Interaction between cyclooxygenase- 2 and inducible nitric oxide synthase in gastric cancer. J Clin Gastroenterol 33: 383-388, 2001.

160. Song ZJ, Gong P, and Wu YE. Relationship between the expression of iNOS,VEGF,tumor angiogenesis and gastric cancer. World J Gastroenterol 8: 591-595, 2002.

161. Song ZY, Wen SQ, Peng JP, Huang X, and Qian KD. Significance of vascular endothelial growth factor expression and its correlation with inducible nitric oxide synthase in gastric cancer. World J Gastroenterol 10: 1250-1255, 2004.

162. Spechler SJ and Souza RF. Barrett's esophagus. N Engl J Med 371: 836-845, 2014.

163. Stuehr DJ. Structure-function aspects in the nitric oxide synthases. Annu Rev Pharmacol Toxicol 37: 339-359, 1997.

164. Sumbayev VV, Budde A, Zhou J, and Brune B. HIF-1 alpha protein as a target for S-nitrosation. FEBS Lett 535: 106-112, 2003.

165. Sun MH, Han XC, Jia MK, Jiang WD, Wang M, Zhang H, Han G, and Jiang Y. Expressions of inducible nitric oxide synthase and matrix metalloproteinase- 9 and their effects on angiogenesis and progression of hepatocellular carcinoma. World J Gastroenterol 11: 5931-5937, 2005.

166. Swierkosz TA, Mitchell JA, Warner TD, Botting RM, and Vane JR. Co-induction of nitric oxide synthase and cyclooxygenase: interactions between nitric oxide and prostanoids. Br J Pharmacol 114: 1335-1342, 1995.

167. Takala H, Saarnio J, Wiik H, Ohtonen P, and Soini Y. HIF1alpha and VEGF are associated with disease progression in esophageal carcinoma. J Surg Res 167: 41-48, 2011.

168. Tamir S, Burney S, and Tannenbaum SR. DNA damage by nitric oxide. Chem Res Toxicol 9: 821-827, 1996.

169. Tang CH, Wei W, and Liu L. Regulation of DNA repair by S-nitrosylation. Biochim Biophys Acta 1820: 730-735, 2012

170. Tate DJ, Jr., Patterson JR, Velasco-Gonzalez C, Carroll EN, Trinh J, Edwards D, Aiyar A, Finkel-Jimenez B, and Zea AH. Interferon-gamma-induced nitric oxide inhibits the proliferation of murine renal cell carcinoma cells. Int $J$ Biol Sci 8: 1109-1120, 2012.

171. Tejero $\mathbf{J}$ and Stuehr D. Tetrahydrobiopterin in nitric oxide synthase. IUBMB Life 65: 358-365, 2013.

172. Thomas DD, Espey MG, Ridnour LA, Hofseth LJ, Mancardi D, Harris CC, and Wink DA. Hypoxic inducible factor 1alpha, extracellular signal-regulated kinase, and p53 are regulated by distinct threshold concentrations of nitric oxide. Proc Natl Acad Sci U S A 101: 8894-8899, 2004.

173. Thomas DD, Heinecke JL, Ridnour LA, Cheng RY, Kesarwala AH, Switzer CH, McVicar DW, Roberts DD, Glynn S, Fukuto JM, Wink DA, and Miranda KM. Signaling and stress: the redox landscape in NOS2 biology. Free Radic Biol Med 87: 204-225, 2015.

174. Thomas DD, Ridnour LA, Isenberg JS, Flores-Santana W, Switzer CH, Donzelli S, Hussain P, Vecoli C, Paolocci N, Ambs S, Colton CA, Harris CC, Roberts DD, and Wink DA. The chemical biology of nitric oxide: implications in cellular signaling. Free Radic Biol Med 45: 18-31, 2008.

175. Thompson WJ, Piazza GA, Li H, Liu L, Fetter J, Zhu B, Sperl G, Ahnen D, and Pamukcu R. Exisulind induction of apoptosis involves guanosine $3^{\prime}, 5^{\prime}$-cyclic monophosphate phosphodiesterase inhibition, protein kinase $\mathrm{G}$ activation, and attenuated beta-catenin. Cancer Res 60: 3338-3342, 2000.

176. Tubino PV, Sarmento BJ, dos Santos VM, Borges ER, da Silva LE, and Lima Rde S. Synchronous oral para- 
coccidioidomycosis and esophageal carcinoma. Mycopathologia 174: 157-161, 2012.

177. Valenzuela MA, Canales J, Corvalan AH, and Quest AF. Helicobacter pylori-induced inflammation and epigenetic changes during gastric carcinogenesis. World J Gastroenterol 21: 12742-12756, 2015.

178. Vincenzi B, Cremolini C, Sartore-Bianchi A, Russo A, Mannavola F, Perrone G, Pantano F, Loupakis F, Rossini D, Ongaro E, Bonazzina E, Dell'Aquila E, Imperatori M, Zoccoli A, Bronte G, De Maglio G, Fontanini G, Natoli C, Falcone A, Santini D, Onetti-Muda A, Siena S, Tonini G, and Aprile G. Prognostic significance of K-Ras mutation rate in metastatic colorectal cancer patients. Oncotarget 6: 31604-31612, 2015.

179. Vinson KE, George DC, Fender AW, Bertrand FE, and Sigounas G. The Notch pathway in colorectal cancer. Int $J$ Cancer 138: 1835-1842, 2016.

180. Wada S, Matsushita Y, Tazawa H, Aoi W, Naito Y, Higashi $\mathrm{A}$, Ohshima $\mathrm{H}$, and Yoshikawa T. Loss of p53 in stromal fibroblasts enhances tumor cell proliferation through nitric-oxide-mediated cyclooxygenase 2 activation. Free Radic Res 49: 269-278, 2015.

181. Wagner DA, Shuker DE, Bilmazes C, Obiedzinski M, Baker I, Young VR, and Tannenbaum SR. Effect of vitamins $\mathrm{C}$ and $\mathrm{E}$ on endogenous synthesis of $\mathrm{N}$-nitrosamino acids in humans: precursor-product studies with [15N]nitrate. Cancer Res 45: 6519-6522, 1985.

182. Wang PL, Liu B, Xia Y, Pan CF, Ma T, and Chen YJ. Long non-coding RNA-low expression in tumor inhibits the invasion and metastasis of esophageal squamous cell carcinoma by regulating p53 expression. Mol Med Rep 13: 3074-3082, 2016.

183. Wang WL, Wang YC, Chang CY, Lo JL, Kuo YH, Hwang TZ, Wang CC, Mo LR, Lin JT, and Lee CT. Human papillomavirus infection on initiating synchronous esophageal neoplasia in patients with head and neck cancer. Laryngoscope 126: 1097-1102, 2016.

184. Wang YZ, Cao YQ, Wu JN, Chen M, and Cha XY. Expression of nitric oxide synthase in human gastric carcinoma and its relation to p53, PCNA. World J Gastroenterol 11: 46-50, 2005.

185. Weinberg RA. The Biology of Cancer. New York: Garland Science, 2007.

186. Wilson KT, Fu S, Ramanujam KS, and Meltzer SJ. Increased expression of inducible nitric oxide synthase and cyclooxygenase- 2 in Barrett's esophagus and associated adenocarcinomas. Cancer Res 58: 2929-2934, 1998.

187. Wink DA and Laval J. The Fpg protein, a DNA repair enzyme, is inhibited by the biomediator nitric oxide in vitro and in vivo. Carcinogenesis 15: 2125-2129, 1994.

188. Wink DA, Miranda KM, and Espey MG. Cytotoxicity related to oxidative and nitrosative stress by nitric oxide. Exp Biol Med (Maywood) 226: 621-623, 2001.

189. Wink DA and Paolocci N. Mother was right: eat your vegetables and do not spit! When oral nitrate helps with high blood pressure. Hypertension 51: 617-619, 2008.

190. Wong MH, Hermiston ML, Syder AJ, and Gordon JI. Forced expression of the tumor suppressor adenomatosis polyposis coli protein induces disordered cell migration in the intestinal epithelium. Proc Natl Acad Sci U S A 93: 9588-9593, 1996.

191. Xia D, Srinivas H, Ahn YH, Sethi G, Sheng X, Yung WK, Xia Q, Chiao PJ, Kim H, Brown PH, Wistuba, II, Aggarwal BB, and Kurie JM. Mitogen-activated protein ki- nase kinase- 4 promotes cell survival by decreasing PTEN expression through an NF kappa B-dependent pathway. $J$ Biol Chem 282: 3507-3519, 2007.

192. Xu W, Liu Z, Bao Q, and Qian Z. Viruses, other pathogenic microorganisms and esophageal cancer. Gastrointest Tumors 2: 2-13, 2015.

193. Xu Z, Huo X, Ye H, Tang C, Nandakumar V, Lou F, Zhang D, Dong H, Sun H, Jiang S, Zhang G, Liu Z, Dong Z, Guo B, He Y, Yan C, Wang L, Su Z, Li Y, Gu D, Zhang X, Wu X, Wei X, Hong L, Zhang Y, Yang J, Gong Y, Tang C, Jones L, Huang XF, Chen SY, and Chen J. Genetic mutation analysis of human gastric adenocarcinomas using ion torrent sequencing platform. PLoS One 9: e100442, 2014.

194. Yang I, Woltemate S, Piazuelo MB, Bravo LE, Yepez MC, Romero-Gallo J, Delgado AG, Wilson KT, Peek RM, Correa P, Josenhans C, Fox JG, and Suerbaum S. Different gastric microbiota compositions in two human populations with high and low gastric cancer risk in Colombia. Sci Rep 6: 18594, 2016.

195. Yang T, Owen JL, Lightfoot YL, Kladde MP, and Mohamadzadeh M. Microbiota impact on the epigenetic regulation of colorectal cancer. Trends Mol Med 19: 714$725,2013$.

196. Yokota S, Okabayashi T, Rehli M, Fujii N, and Amano K. Helicobacter pylori lipopolysaccharides upregulate tolllike receptor 4 expression and proliferation of gastric epithelial cells via the MEK1/2-ERK1/2 mitogenactivated protein kinase pathway. Infect Immun 78: 468476, 2010.

197. Zhang W, He XJ, Ma YY, Wang HJ, Xia YJ, Zhao ZS, Ye $\mathrm{ZY}$, and Tao HQ. Inducible nitric oxide synthase expression correlates with angiogenesis, lymphangiogenesis, and poor prognosis in gastric cancer patients. Hum Pathol 42: 1275-1282, 2011.

Address correspondence to: Dr. David A. Wink Cancer and Inflammation Program Center for Cancer Research National Cancer Institute National Institutes of Health Building 567 Room 254 1050 Boyle's Street Frederick, MD 21702

E-mail: wink@mail.nih.gov

Date of first submission to ARS Central, August 2, 2016; date of acceptance, August 5, 2016.

$$
\begin{aligned}
& \text { Abbreviations Used } \\
& \mathrm{ACC}=\text { adrenocortical carcinoma } \\
& \mathrm{ACF}=\text { aberrant crypt foci } \\
& \mathrm{AIF}=\text { apoptosis-inducing factor } \\
& \mathrm{Akt}=\text { protein kinase } \mathrm{B} \\
& \mathrm{APC}=\text { adenomatous polyposis coli } \\
& \mathrm{BE}=\text { Barrett's esophagus } \\
& \mathrm{BLCA}=\text { bladder invasive carcinoma } \\
& \mathrm{BRCA}=\text { breast invasive carcinoma } \\
& \mathrm{CD}=\text { Crohn's disease }
\end{aligned}
$$




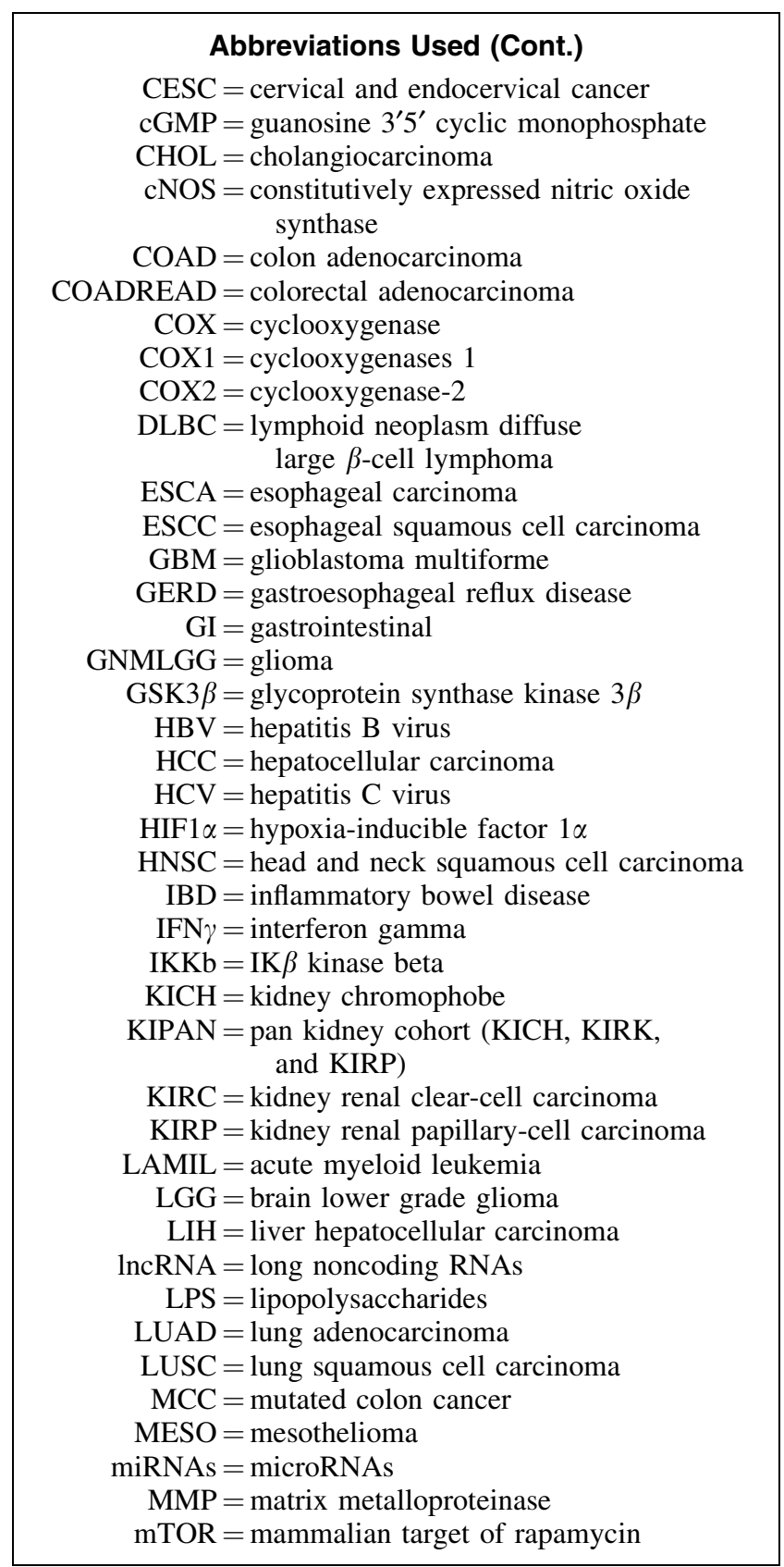

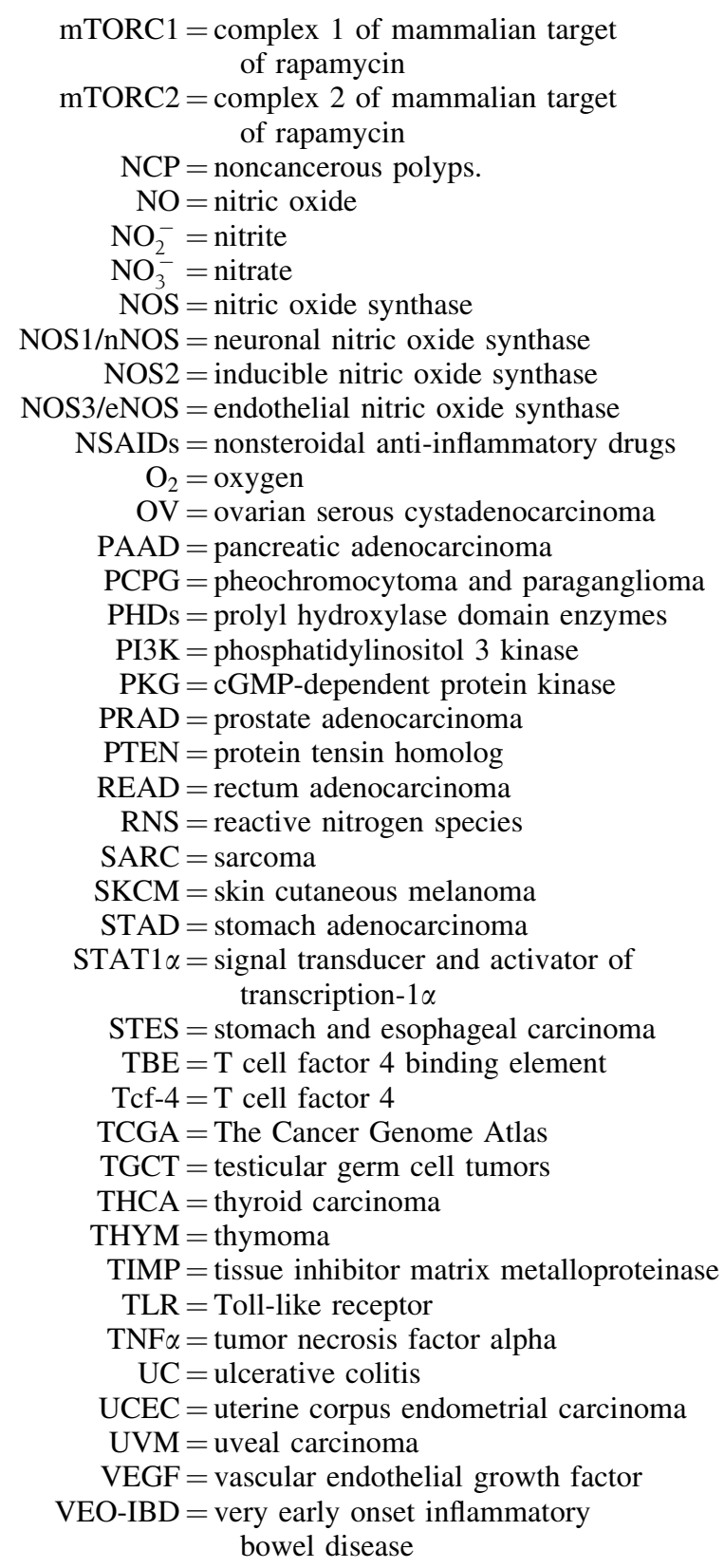

